\title{
INTERNETY SIĘ PALĄ. O WYBRANYCH SEMIOTYZACJACH POŻARU KATEDRY NOTRE DAME
}

MAŁGORZATA JANKOWSKA

Instytut Kulturoznawstwa UAM

Institute of Cultural Studies, Adam Mickiewicz University in Poznań helga82@amu.edu.pl

\section{SEMIOTYZACJA. OD MEDIALNEGO „FAKTU” DO ZNAKU}

Nie sposób orzec, jak historia (czy historiografia) obejdzie się z pożarem katedry Notre Dame i czy w ogóle wydarzenie to stanie się przedmiotem jej zainteresowania (poza granicami historii sztuki, która, rzecz jasna, odnotować musi ten fakt w swych annałach). Nie da się jednak nie zauważyć, że w czasie rzeczywistym, w medialnym zapośredniczeniu wprawdzie, jednak w iluzji dostępu, natychmiastowości i właśnie - bezpośredniości, stał się on wydarzeniem o niezliczonych, konstruowanych na gruncie rozmaitych dyskursów, znaczeniach. W społecznym odbiorze, którego echa pojawiały się w dużym natężeniu w przestrzeni mediów społecznościowych, pożar szybko przestał być li tylko faktem czy zjawiskiem, a stał się jeśli nie symbolem, to przynajmniej znakiem, szyfrem lub komunikatem danym do odczytania, przy czym owe rozmaite jego interpretacje stawały się kolejnymi znakami, odczytywanymi z kolejnych perspektyw i na poziomie kolejnych dyskursów, zgodnie z zasadą nieograniczonej semiozy.

W zapośredniczonej (i jednocześnie - wytwarzanej) medialnie społecznej czy kulturowej recepcji zdarzenia dostrzec można zatem mechanizm usemiotyczniania pożaru i wpisywania tak re-konstruowanego znaku / symbolu / komunikatu w obszar rozlicznych mikrowojen kulturowych. Dominują tu narracje przestrogi, upadku, zbliżającego się końca świata, kary czy sygnału, a wytwarzane znaczenia często „żerują semiotycznie” z jednej strony na (biblijnej) symbolice ognia, z drugiej - na odczytywaniu samej 
katedry jako symbolu lub znaku (w zależności od przyjętej w danym odczytaniu optyki), przy czym przydawane jej sensy wykraczają poza historyczną semiotykę katedry jako takiej (lub nawet całkowicie ją pomijają), a nawet poza jakąkolwiek semiotykę przestrzenną, wytwarzając w zamian nowe konglomeraty znaczeń, przykładowo - kanonizując budowlę jako „symbol chrześcijaństwa”, „symbol cywilizacji europejskiej”, „symbol Paryża/ Francji” etc. Przy czym są to w tym kontekście, by tak rzec, „semiotyzacje pierwotne" - semiotyzacje wtórne skupiają się natomiast na tych pierwszych jako na znakach (o czym szerzej nieco dalej).

W rozlicznych narracjach osnutych wokół interesującego nas wydarzenia dominują nastroje quasi-apokaliptyczne. Pożar jawi się jako komunikat dany do odczytania, a na zmediatyzowaną rzeczywistość nakładana jest nierzadko interpretacyjna i semiotyczna matryca teksów biblijnych. Jak zauważa Umberto Eco, choć wprawdzie to światy fikcyjne są pasożytami świata prawdziwego, to jednocześnie w sytuacji, gdy czytelnik zrywa „umowę o fikcyjności”, granice zaczynają się zacierać: fikcja nie tyle już „pasożytuje na rzeczywistości”, co ją przerasta i podbija. Dzieje się to zgodnie z zasadą wprowadzania fikcyjnych elementów do interpretowanej rzeczywistości, które tym samym nabierają cech „prawdziwości”, niejednokrotnie (celowo) „ukrytej”. Jeśli w miejsce terminu „fikcja” wstawić słowo „tekst”, dostrzec można, że to właśnie opisany powyżej mechanizm odpowiada w dużej mierze za (nad)semiotyzację paryskich wydarzeń. Warto nadto zauważyć, że tekst, który stanowi jedną z głównych ram interpretacyjnych dla omawianego zdarzenia (acz, podkreślmy, nie jedyną, co ukażą analizowane dalej egzempla), jest zarówno tekstem świętym (z perspektywy religijnej), jak i, w szerszym oglądzie, tekstem kulturowym (Aleida Assmann²) - dostarcza

1 Zob. U. Eco, Fikcyjne „Protokoły”, [w:] idem, Sześć przechadzek po lesie fikcji, tłum. J. Jarniewicz, Kraków 1996.

2 Aleida Assmann przeprowadza rozróżnienie między tekstem literackim a tekstem kulturowym, wskazując na cztery podstawowe różnice objawiające się w: 1. związku z tożsamością, 2. sposobie odbioru, 3. wymogu innowacyjności i włączenia do kanonu oraz 4. ponadczasowości. Tekst kulturowy zatem kierowany jest do odbiorcy jako członka konkretnej wspólnoty, zanurzonego w jej tradycji, bazującej właśnie m.in. na treściach przekazywanych przez ów tekst, jego rolą jest zakorzenienie odbiorcy $\mathrm{w}$ danej zbiorowości, a dalej - zakotwiczenie tejże 
zatem bazowego kodu, na którym narastać może polijęzyczny, wielowarstwowy komunikat, tak o charakterze quasi-religijnym, jak i niereligijnym, a nawet anty-religijnym (choć narracja antyreligijna, jak się okaże, skierowana jest $\mathrm{w}$ tym przypadku w stronę islamu, żerując na uaktualnionych i przekodowanych narracjach wojny religijnej czy krucjaty). Tekst kanoniczny zatem, wraz z jego spauperyzowanymi egzegezami, służy przekodowaniu informacji w nowy komunikat.

Eco, analizując przemieszanie porządków literatury i rzeczywistości, zwraca uwagę na tendencję do totalnej semiotyzacji tak tekstu, jak i rzeczywistości - to dostrzeganie wszędzie znaków i znaczeń, percypowanie znaków jako symboli, umieszczanie elementów tekstu w nowym, „Wreszcie właściwym” kontekście. Rozliczne semiotyzacje pożaru katedry Notre Dame wpisują się ten schemat. W niektórych przypadkach skrajnie apokaliptycznych interpretacji semiotyzacja owa może być widziana jako słabe odbicie poznawczej (czy nawet - metafizycznej) tendencji do deszyfryzacji rzeczywistości. Jak bowiem zauważa Eco: „Istnieje założenie, które przyjmują wszyscy specjaliści od łamania szyfrów i kodów - każdy tajny komunikat może zostać rozszyfrowany, pod warunkiem, że wiemy, iż jest to komunikat. Problem, przed jakim stawia nas świat rzeczywisty od samego zarania, dotyczy tego, czy w ogóle istnieje jakiś komunikat, a jeśli tak, czy jest to komunikat sensowny"3. Deszyfracja opiera się zatem na przekonaniu, że za danym tekstem czy zjawiskiem kryje się (tajemne) znaczenie, wymagające odczytania. Z założenia tego wyrastają procesy re-konstruowania nowych związków syntagmatycznych, mających ukazać to, co ukryte pod pozorem

zbiorowości w historii (nierzadko mitycznej). Formuje on zatem zbiorowe „Ja”. Tekst kulturowy jest trwały, niezmienny, opiera się „wymogowi nowości”, pozostając „nieustannie aktualnym” jako komunikat bazowy dla danej formacji kulturowej. W końcu - tekst kulturowy podlega procesowi kanonizacji, która zapobiega jego historyzacji i zrelatywizowaniu do konkretnych warunków, w których powstał. Zob. A. Assmann, Czym sq teksty kulturowe?, tłum. A. Konarzewska, [w:] eadem, Między historią a pamięcią. Antologia, red. i posłowie M. Saryusz-Wolska, Warszawa 2013, s. 35-38.

3 U. Eco, Dziwny przypadek ulicy Servandoni, [w:] idem, Sześć przechadzek..., op. cit., s. 131. 
oczywistych, banalnych relacji międzyznakowych. Odbiorca sam sobie jawi się jako odkrywca, czytelnik świadomy, detektyw czy nawet prorok.

Rozmaite odczytania pożaru jawić się w końcu mogą ich autorom jako przeniesienie informacji (zapośredniczonej medialnie) we „wreszcie właściwy kontekst", na zasadzie Łotmanowskiego schematu asymilacji komunikatów $w^{4}$. Z tego punktu widzenia quasi-transparentne komunikaty medialne nawet jeśli nie zakłamują rzeczywistości, to jednak „nie odsłaniają istoty rzeczy" - należy je zatem twórczo przełożyć, zasymilować właśnie, by zyskały właściwy wymiar.

Co istotne, choć media społecznościowe dosłownie zawrzały w reakcji na paryski dramat, to jednak reakcje te były zróżnicowane. Nastąpiła redundancja komunikatów z różnych rejestrów - od „smutnej powagi”, przez (nierzadko niepozbawiony satysfakcji) sztafaż apokaliptyczny, po pastisz, ironię i żart. Chciałabym skupić się na reakcjach przede wszystkim „polskiego Internetu" i próbie, fragmentarycznego z konieczności, naszkicowania linii frontu rozmaitych mikrowojen kulturowych, które w reakcjach owych znajdują odzwierciedlenie. Nie podejmuję się tu dyskutowania kwestii "ontologicznych", czyli pytania, na ile omawiane reakcje stanowią owoc działalności trolli i botów - nie chodzi przy tym o to, że pytanie takie jest bezzasadne, lecz o to, że nawet uznając część wspomnianego materiału za efekt retorycznie i/lub politycznie warunkowanego trollingu, wciąż widzieć w nim można dokumentację pewnych podziałów i linii napięć (nawet jeśli są one nie tylko ilustrowane, ale i prowokowane).

4 Jurij Łotman dzieli proces przyswajania obcych komunikatów na pięć faz. W fazie pierwszej teksty z zewnątrz zachowują status obcych; w drugiej teksty obce i kultura przyjmująca wzajemnie się przebudowują, w rezultacie powstają przeróbki, adaptacje i przekłady; w fazie trzeciej pojawia się tendencja do oddzielania tekstu asymilowanego od jego kontekstu oryginalnego - widzianego jako „niewłaściwy” i traktowanie go odtąd jako umieszczonego we „wreszcie właściwym kontekście”; w fazie czwartej teksty obce ostatecznie rozpływają się w kulturze odbiorczej, która generować zaczyna mnogość nowych komunikatów, opartych na tych już zasymilowanych. Zob. J. Łotman, Mechanizmy dialogu, [w:] idem, Uniwersum umystu. Semiotyczna teoria kultury, tłum. B. Żyłko, Gdańsk 2008, s. 227. 


\section{SYMBOLIKA OGNIA. KRÓTKI ZARYS}

Jak podkreśla Umberto Eco, „ogień ma [...] wiele przejawów i - poza tym, że jest zjawiskiem fizycznym - staje się symbolem, jak wszystkie symbole jest dwuznaczny, polisemiczny i odwołuje się do wielu znaczeń, w zależności od kontekstu"5. Ogień odgrywa znaczącą rolę w mitologiach, w religiach, w filozofiach, a jako taki - również w psychoanalizie, gdzie stanowi między innymi metaforę popędów, zmiany, życia i przemijalności ${ }^{6}$.

Eco zauważa, że ze względu na swą naturę - efemeryczną, niebezpieczną i życiodajną zarazem - a także na konotacje ze słońcem, ogień nieustannie, w rozmaitych kulturach i religiach, kojarzony był z boskością ${ }^{7}$. Symbolika ognia niebagatelną rolę odgrywa również w Piśmie Świętym. Jak stwierdza

5 U. Eco, Płomień jest piękny, [w:] idem, Wymyślanie wrogów i inne teksty okolicznościowe, tłum. A. Gołębiowska, T. Kwiecień, Poznań 2011, s. 72.

${ }^{6}$ Eco przywołuje w tym miejscu myśl Gastona Bachelarda, syntetyzując jego rozważania o ogniu: „[...] ogień stanowi metaforę wielu popędów - od rozpalania się gniewem do płomieni miłosnego zauroczenia; ogień jest metaforycznie obecny w każdym dyskursie o emocjach, tak jak łączy się go metaforycznie z życiem poprzez kolor, który dzieli z krwią. Ogień jako ciepło stymuluje przemianę materii podczas trawienia, a z procesem trawiennym łączy go także to, że aby żyć, musi być wciąż dokarmiany. Ogień jawi się jednoznacznie jako narzędzie wszelkiej przemiany i gdy chce się coś zmienić, używa się ognia. Aby nie zgasł, ogień wymaga troski, takiej jaką otacza się noworodka; w ogniu widać jak na dłoni fundamentalne sprzeczności naszego życia, jest on żywiołem dającym życie, ale niosącym także śmierć, zniszczenie oraz cierpienie, jest symbolem czystości, oczyszczenia, ale również brudu, gdyż wytwarza popiół jako swój ekskrement. [...] Ogień rodzi się z materii, by przemienić się w substancję coraz lżejszą i bardziej lotną, od czerwieni lub niebieskawości u podstawy do bieli szczytu, by w końcu zaniknąć w smużce dymu... W takim znaczeniu natura ognia jest wstępująca, odsyła nas do transcendencji, a przy tym, może dlatego, że zrozumiano, iż żyje on w sercu Ziemi, skąd wytryskuje jedynie podczas przebudzenia wulkanów, jest także symbolem otchłani. Jest życiem, ale też doświadczeniem przemijalności i kruchości”. Ibidem, s. 70-71.

7 Zob. ibidem, s. 73. 
Jan Kanty Pytel, w obu Testamentach słowo „ogień” użyte jest aż 472 razy, w większości przypadków w znaczeniu symbolicznym ${ }^{8}$.

Jak podkreśla Eco, ogień jako symbol ma bogatą semantykę - tak też i przedstawienia ognia w Piśmie Świętym niosą rozmaite konotacje. Wiąże się on między innymi z kultem ofiarniczym, do czego wiele odniesień znajduje się zwłaszcza w Starym Testamencie. Jak zauważa Antoni Tronina:

Po raz pierwszy w tym kontekście [kultu ofiarniczego - M.J.] czytamy o ogniu w nakazie konsekracji Aarona i jego synów. Materią ofiary przebłagalnej ma być w tym przypadku tłuszcz młodego cielca, spalany na ołtarzu. „Lecz mięso cielca i jego skórę i mierzwę spalisz w ogniu poza obozem" - nakazuje Bóg Mojżeszowi (Wj 29,14). „Prawo ofiar”, zawarte w pierwszej części Księgi

8 „Stary Testament zna siedem pojęć hebrajskich na ogień, które w przekładzie Septauginty mają swe ekwiwalenty w greckich pyr (ogień), pyroo (palę), phlogidzo (płonę). Pojęcie $p y r$ - »ogień« ma niekiedy przydawki, i tak:

a) pyr katanaliskon - »ogień pochłaniający« (Hbr 12,29; zob. Pwt 4,24; Iz 33,14). Ogień jest w tym przypadku symbolem Bożej sprawiedliwości, która jest groźna dla odstępów i prześladowców. Potwierdza to kontekst, w którym hagiograf zapowiada zniszczenie tego, co może podlegać zniszczeniu, i trwanie tego, co niezniszczalne, niewzruszone, tj. Królestwa, gdzie przez łaskę trwają wierzący.

b) pyr phlegon - »ogień płonący« (Ap 1,14), związany z symboliką oczu, w kontekście którego ukazuje Chrystusa zmartwychwstałego jako nieomylnego, bo wszystko widzącego Sędziego: »Oczy Jego jak płomień ognia« (Ap 1,14).

c) pyr phlegomenon - w tłumaczeniu Wulgaty ignis ardens (Mdr 16,22). Hagiograf reinterpretuje tutaj we wspaniałej syntezie, w perspektywie zbawczej, mannę (Zob. Wj 16,15-16; Iz 65,6). Manna była nietrwała, podobna do śniegu i lodu, ale wytrzymała ogień, nie topniała. A tymczasem plony nieprzyjacielskie niszczył $p y$ rphlegomenon - ignis ardens, który płonął wśród gradu i żarzył się w czasie ulewy. d) pyr kai libanos epi pyreiou - »jak ogień i kadzidło w kadzielnicy« (Syr 50,9). Wulgata tłumaczy cytowany zwrot ignis effulgens - »ogień jaśniejący«. Autor natchniony jak artysta wysławia w tzw. pochwale Ojców arcykapłana Szymona i podziwia jego wielkość, która była dziełem Boga. W tej wielkości przejawiała się chwała Boża w ludzie wybranym Starego Testamentu. Odniesienie słów »jak ogień i kadzidło w kadzielnicy« do arcykapłana Szymona symbolizuje żarliwość, spalenie się w służbie Bożej, a także trwały przykład »z pokolenia na pokolenie«, co sugeruje Wulgata przez swoje tłumaczenie: ignis effulgens". J.K. Pytel, Symbolika ognia w Piśmie Świętym, „Ruch Biblijny i Liturgiczny” 1989, t. 42, nr 2, s. 115-116. 
Kapłańskiej (1-7), wielokrotnie mówi o znaczeniu ognia podczas składania ofiar całopalnych. „Ogień nieustanny będzie płonąć na ołtarzu - nigdy nie będzie wygasać!” (Kpł 6,6). Kiedy dwaj synowie Aarona „ofiarowali przed Panem ogień inny, niż był im nakazany, wtedy wyszedł ogień od Pana i pochłonął ich" (Kpł 10,1-2). Najważniejszy jednak jest opis liturgii Dnia Pojednania, kiedy to Aaron winien najpierw złożyć „ofiarę przebłagalną za siebie samego. Następnie weźmie pełną kadzielnicę węgli rozżarzonych $\mathrm{z}$ ołtarza, który jest wobec Pana, i dwie pełne garści kadzidła w proszku, i wniesie je poza zasłonę. Rzuci kadzidło na ogień przed Panem, tak iż obłok kadzidła okryje przebłagalnię, która jest na [Arce] Świadectwa. Dzięki temu nie umrze" (Kpł 16,11-13) .

Ogień w kulcie ofiarniczym z jednej strony oczyszcza ofiarę, czyniąc ją „odpowiednią” dla Boga - jak w Księdze Kapłańskiej, gdzie „ogień zniszczenia” pożera nieczyste części zwierząt ofiarnych (Kpł 4,12; 7,19; 9,11; 16,27), z drugiej zaś, jako „ogień pożerający” jest odpowiedzią Boga, znakiem przyjęcia ofiary, jak w przypadku sądu Eliasza nad kapłanami Baala ${ }^{10}$ - stanowi zatem formę komunikacji Absolutu z człowiekiem. Dla Żydów ogień był znakiem przymierza, stąd płynęła konieczność nieustannej dbałości o jego ciągłość (wokół tej kwestii zresztą osnute były rozmaite apokryfy i legendy, które wywierały następnie pośredni wpływ na chrześcijańską symbolikę ognia, choć była ona, rzecz jasna, umocowana przede wszystkim w przekazach kanonicznych ${ }^{11}$ ). W religii mojżeszowej, jak zauważa

9 A. Tronina, Eucharystia. Ogień i duch, „Verbum Vitae” 2005, nr 8, s. 102.

10 „Niech nam dadzą dwa młode cielce. Oni niech wybiorą sobie jednego cielca i porąbią go oraz niech go umieszczą na drwach, ale ognia niech nie podkładają! Ja zaś oprawię drugiego cielca oraz umieszczę na drwach i też ognia nie podłożę. Potem wy będziecie wzywać imienia waszego boga, a następnie ja będę wzywał imienia Pana, aby się okazało, że ten Bóg, który odpowie ogniem, jest [naprawdę] Bogiem” (1 Krl. 18,23-24).

11 Jak pisze A. Tronina: „Tradycja żydowska głosi, »że prorok Jeremiasz rozkazał, aby ci, którzy zostali uprowadzeni do niewoli, wzięli ze sobą ogień" (2 Mch 2,l). Sam natomiast prorok ukrył w pieczarze na świętej górze (Nebo) »namiot, arkę i ołtarz kadzenia«. Legenda o świętym ogniu została przekazana diasporze aleksandryjskiej w liście wprowadzającym do Drugiej Księgi Machabejskiej. Tradycja ta jest wyrazem przekonania, że »ofiara nieustanna« (tamid) świątyni jerozolimskiej była 
Bogusław Nadolski, ogień jest przede wszystkim „[...] znakiem obecności boskiej, podstawowym elementem teofanii, znakiem świętości, do której śmiertelny człowiek nie ma dostępu (góra Horeb - Synaj, krzak gorejący, zawarcie przymierza z Abrahamem, obecność czuwającego Boga podczas wędrówki przez pustynię: Wj 13,21-22; 14,24; 24,15-17; 40,34-38; Ne 9,12-19). Ogień jest widzialnym znakiem Niewidzialnego (Iz 6,1-7; Ez 1,27-28)"12. Ogień jako znak boskiej obecności, pojawiający się zarówno w Starym, jak i w Nowym Testamencie, może przy tym oznaczać zarówno „oświecającą obecność”, epifanię czy blask chwały, jak i wywołującą trwogę potęgę, która zniszczyć może wszystko, co się jej przeciwstawia ${ }^{13}$. Ogień symbolizuje więc Boga, uświęcenie, przymierze, majestat, a w Nowym Testamencie także

kontynuowana przez deportowanych w Babilonii. Zrozumiałe, że pisarze chrześcijańscy będą widzieli w tych podaniach, częściowo apokryficznych, zapowiedź Ofiary nowego i wiecznego Przymierza. Filon z Aleksandrii w swych Alegoriach Praw posługuje się chętnie symboliką ognia ofiarnego. W nawiązaniu do biblijnego opisu drogich kamieni umieszczonych na szacie arcykapłana wyjaśnia on powołanie duchowe dwunastu pokoleń Izraela. Szczególną rolę ma tu do spełnienia Juda, którego imię wykłada się jako »wyznawca Boga«. Wyznawcy przysługuje barwa rubinu, ponieważ płonie on uczuciem wdzięczności względem Boga (pepyromenos en eucharistia Theou)". A. Tronina, op. cit, s. 102-103.

${ }_{12}$ Leksykon liturgii, oprac. B. Nadolski, Poznań 2006, s. 393.

13 Jak pisze Andrzej Rojewski: „Historyczne księgi Starego Testamentu wielokrotnie wzmiankują o objawieniu się Boga pod postacią ognia, który spalał przedmioty materialne. Jednak w pismach Starego i Nowego Testamentu nie brak miejsc, w których ukazujący się ogień nie pochłania przedmiotów, a jedynie oświeca. W tych fragmentach chodzi zatem albo o niematerialne zjawisko, albo o wyłącznie obrazową formę wyrazu: w blasku ognia chwałę Pana ogląda Ezechiel i Daniel (Ez 1; Dn 7,9), zaś wizjoner z Patmos kreśli obraz Syna Człowieczego, którego oczy są jak płomienie ognia, a nogi jak rozżarzona ruda złota (Ap 1,15; 2,18)”. A. Rojewski, Symbolika światła w liturgii, „Studia Płockie” 2010, nr 38, s. 169. Dla Dorothei Forstner ogień obrazuje wszechwiedzę Syna Człowieczego oraz jego potęgę, „która wszystko, co Mu się sprzeciwi, może zdeptać i zniszczyć”. D. Forstner, Świat symboliki chrześcijańskiej, tłum. i oprac. W. Zakrzewska, P. Pachciarek, R. Turzyński, Warszawa 1990, s. 74. 
Chrystusa, pojawiając się przy tym w licznych kontekstach ${ }^{14}$, konotując zarówno moc zbawczą, jak i karzącą. Jak zauważa Andrzej Rojewski, bogata symbolika ognia ujawnia się między innym w liturgii Wigilii Paschalnej, w której ważnym elementem jest właśnie błogosławienie ognia, krzesanego

${ }^{14}$ Częściowo konteksty te wylicza Paweł Gocko: „Księga Wyjścia w sposób szczególny ukazuje nam przebóstwiony charakter ognia jako zjawisko, pod którym sam Bóg objawia się człowiekowi. Mojżesz po raz pierwszy spotkał Boga pod postacią gorejącego krzewu: »Wtem ukazał mu się anioł Pański w płomieniu ognia ze środka krzewu; i spojrzał, a oto krzew płonął ogniem, jednakże krzew nie spłonął (Wj 3,2). Po wyjściu Izraelitów z ziemi egipskiej Bóg ukazywał swemu ludowi drogę nocą jako słup ognia (Wj 40,38). Ogień był znakiem obecności Boga i okrywał pierwszą świątynię Boga - Namiot Zgromadzenia: „W dniu, kiedy ustawiono przybytek, okrył go wraz z Namiotem Świadectwa obłok i od wieczora aż do rana pozostawał nad przybytkiem na kształt ognia. I tak działo się zawsze: obłok okrywał go w dzień, a w nocy - jakby blask ognia« (Lb 9,15-16). Później sam Bóg zostaje w końcu porównany do ognia: »Gdyż Pan, Bóg twój, jest ogniem trawiącym« (Pwt 4,24). Prorok Jeremiasz porównuje także Słowo Boże do ognia (Jer 23,29). Trzej młodzieńcy w niewoli babilońskiej zostali wrzuceni do potężnego ognia, który nie wyrządził im żadnej krzywdy i stał sięźródłem chwały Boga Izraela (Dn 3,1-97). Towarzyszy także potężnemu Majestatowi Boskiemu, o czym pisze Prorok Daniel: »Patrzyłem, aż postawiono trony, a Przedwieczny zajął miejsce. [...] Tron Jego był z ognistych płomieni, jego koła - płonący ogień. Strumień ognia się rozlewał i wypływał od Niego" (Dn 7,9-10). Poświęcenie Świątyni Jerozolimskiej miało miejsce za pośrednictwem błogosławieństwa ognia zstępującego z nieba: »A gdy Salomon zakończył modlitwę, spadł ogień z niebios i strawił ofiarę całopalną i ofiary rzeźne $(2 \mathrm{Krl} 7,1)$. Podobne błogosławieństwo ognia miało miejsce na Górze Karmel, aby uświęcić ofiarę proroka Eliasza i nawrócić lud Izraela, który oddawał się bałwochwalstwu (1 Krl 18,19-40). Powtórne poświęcenie Świątyni w 164 r. p.n.e., po jej zbezczeszczeniu przez pogan, zapoczątkowało także słynne żydowskie święto Świateł - Chanukę (1 Mch 4,56-59), zwane także świętem ognia: "Mając obchodzić Oczyszczenie Świątyni dwudziestego piątego Kislew, uważaliśmy, że trzeba wam o tym donieść, abyście wy także obchodzili Święto Namiotów i ognia na pamiątkę tego, jak Nehemiasz odbudował Świątynię i Ołtarz, a potem złożył ofiary« (2 Mch 1,18). Ogień w Starym Testamencie miał znaczenie Boskie, mistyczne i oczyszczające”. P. Gocko, Mistyczne znaczenie ognia, „Elpis. Czasopismo Teologiczne Katedry Teologii Prawosławnej Uniwersytetu w Białymstoku" 2017, nr 19, s. 10. 
z kamienia - co odnosi się do wyprowadzania kosmosu $\mathrm{z}$ chaosu ${ }^{15} \mathrm{i}$ do Chrystusa jako zasady wszechświata ${ }^{16}$. Z kolei Tronina podkreśla wspomnianą wyżej dwuznaczną, pozornie opozycyjną, a w istocie komplementarną funkcję ognia jako zarazem błogosławieństwa i kary, zwłaszcza w kontekście interpretacji słów Ewangelii wg św. Łukasza:

Gdy dopełnił się czas Jego wzięcia [z tego świata - M.J.], postanowił udać się do Jerozolimy i wysłał przed sobą posłańców. Ci wybrali się w drogę i przyszli do pewnego miasteczka samarytańskiego, by Mu przygotować pobyt. Nie przyjęto Go jednak, ponieważ zmierzał do Jerozolimy. Widząc to, uczniowie Jakub i Jan rzekli: „Panie, czy chcesz, a powiemy, żeby ogień spadł z nieba i zniszczył ich?”. Lecz On odwróciwszy się zabronił im. I udali się do innego miasteczka (Łk 9, 51-56).

\section{I dalej:}

Przyszedłem rzucić ogień na ziemię i jakże bardzo pragnę, żeby on już zapłonął. Chrzest mam przyjąć i jakiej doznaję udręki, aż się to stanie. Czy myślicie, że przyszedłem dać ziemi pokój? Nie, powiadam wam, lecz rozłam (Łk 12, 49-51).

Jak głosi komentarz w Biblii Tysiąclecia, ogień, do którego odnosi się Jezus, to ogień, „który oczyści i zapali serca, a który zapłonie na krzyżu”, co zyskuje pełnię znaczenia w kontekście między innymi Ewangelii Janowej (komentarz odsyła czytelnika przede wszystkim do: J 12,32) ${ }^{17}$. Tronina zauważa, że

„Chrzest”, który Jezus ma przyjąć, oznaczałby zatem Jego śmierć jako konieczny warunek posłania „ognia” na ziemię. W teologii św. Łukasza (Dz 2,3.31-33) jest to zapowiedź zesłania Ducha Świętego na Kościół po męce Jezusa. Spełnia się zapowiedź eschatologicznego sądu przez „ogień”. Jezus jednak uobecnia ten sąd w sposób, który przekracza wszelkie o nim wyobrażenie: On sam ściąga na siebie ten ogień Bożego gniewu, aby okazać solidarność z grzeszną ludzkością. Odtąd postawa wobec Jezusa decyduje

15 Zob. A. Rojewski, op. cit., 180-181.

16 Zob. ibidem.

17 https://biblia.deon.pl/rozdzial.php?id=351\&werset=32\#W32 [dostęp: 3.09.2019]. 
o wiecznym losie człowieka. Ponowne przyjście Chrystusa w ciele to według św. Mateusza ostateczne „oddzielenie” dwóch rzeczywistości wiecznych, którymi są „ogień” i „królestwo” ${ }^{18}$.

Ogień karzący to przede wszystkim apokaliptyczny ogień z nieba oraz jezioro siarki i ognia:

I przyszedł inny anioł, i stanął przy ołtarzu, mając złote naczynie na żar, i dano mu wiele kadzideł, aby dał je w ofierze jako modlitwy wszystkich świętych, na złoty ołtarz, który jest przed tronem. I wzniósł się dym kadzideł, jako modlitwy świętych, z ręki anioła przed Bogiem. Anioł zaś wziął naczynie na żar, napełnił je ogniem z ołtarza i zrzucił na ziemię, a nastąpiły gromy, głosy, błyskawice, trzęsienie ziemi. A siedmiu aniołów, mających siedem trąb, przygotowało się, aby zatrąbić. I pierwszy zatrąbił. A powstał grad i ogień - pomieszane $z$ krwią, i spadły na ziemię. A spłonęła trzecia część ziemi i spłonęła trzecia część drzew, i spłonęła wszystka trawa zielona. I drugi anioł zatrąbił: i jakby wielka góra płonąca ogniem została w morze rzucona, a trzecia część morza stała się krwią i wyginęła w morzu trzecia część stworzeń - te, które mają dusze - i trzecia część okrętów uległa zniszczeniu. I trzeci anioł zatrąbił: i spadła z nieba wielka gwiazda, płonąca jak pochodnia, a spadła na trzecią część rzek i na źródła wód (Ap 8,3-10).

Wyszli oni na powierzchnię ziemi i otoczyli obóz świętych i miasto umiłowane; a zstąpił ogień od Boga z nieba i pochłonął ich. A diabła, który ich zwodzi, wrzucono do jeziora ognia i siarki, tam gdzie są Bestia i Fałszywy Prorok. I będą cierpieć katusze we dnie i w nocy na wieki wieków (Ap 20,9-10).

I morze wydało zmarłych, co w nim byli, i Śmierć, i Otchłań wydały zmarłych, co w nich byli, i każdy został osądzony według swoich czynów. A Śmierć i Otchłań wrzucono do jeziora ognia. To jest śmierć druga - jezioro ognia. Jeśli się ktoś nie znalazł zapisany w księdze życia, został wrzucony do jeziora ognia (Ap 20,13-15).

Ogień karzący, Dzień Sądu, ogień piekielny - pojawiają się również w innych miejscach Pisma Świętego oraz w egzegezach czynionych na gruncie

18 A. Tronina, op. cit., s. 104. 
różnych konfesji chrześcijańskich ${ }^{19}$. Zresztą wizja kary z ognia powiązana jest również z opowieścią o zniszczeniu Sodomy - jawi się jako kara za grzechy, symbolizując zagładę, która czeka upadłych i zatwardziałych w grzechu i sprzeciwie wobec Boga:

19 „Właściwością mistycznego znaczenia ognia jest to, że może on służyć celom dobrym i przebóstwionym, ale także celom złym i nieczystym. Ogień może przynosić cierpienie. Może być zarówno źródłem dobra i ciepła, jak i źródłem nieszczęścia i cierpienia. Jest żywiołem niszczącym materię w pożarze, a także żywiołem, który jest narzędziem wiecznego potępienia - mąk w ogniu piekielnym. Jest on nazywany ogniem niegasnącym i, jak pisze św. Grzegorz Palamas, "posiada niewyczerpane źródło palenia się, a jest to właśnie unaocznienie sił piekielnych«. Św. Jan Złotousty tłumaczy, iż w odróżnieniu od ognia materialnego, który spala i niszczy wszystko, co pochłonie, ogień piekielny wiecznie pali tych, którzy trafią w jego płomienie i nigdy nie słabnie. Dlatego też nazywany jest niegasnącym. Św. męczennik Justyn Filozof mówi o szatanie, że wpadnie on »w ogień ze swoim wojskiem « i że ci, którzy kroczą za nim, będą męczyć się »bez końca«. Z kolei św. Jan Damasceński podkreśla, iż nie jest to ogień naturalny, a jego naturę zna jedynie sam Bóg. Przypowieść o bogaczu i ubogim Łazarzu daje nam pewne niejasne wyobrażenie o ogniu piekielnym (Łk 16,19-31). Dowiadujemy się w niej, iż po śmierci bogacz został pozbawiony wszystkiego, czym cieszył się za życia. Doświadcza nieznośnych cierpień, niezaspokojonego pragnienia, strachu, trwogi i nieustannych wyrzutów sumienia, których Bóg nie przyjmuje, gdyż ujawniają się dopiero po śmierci. Bogacz jednocześnie rozpacza nad tym, że ci, którymi gardził, choćby Łazarz, rozkoszują się dziś wiecznym szczęściem i błogosławieństwem. W przypowieści trudno jednoznacznie określić miejsce męki bogacza, ale można zauważyć, że to właśnie ogień jest bezpośrednią przyczyną jego cierpień. Woła on do Abrahama: »Ojcze Abrahamie, ulituj się nade mną i przyślij Łazarza, aby koniec swego palca umoczył w wodzie i ochłodził mój język, bo strasznie cierpię w tym płomieniu« (Łk 16,24). Pomimo tego, że ogień trawi go w całości, to prosi jedynie o umoczony koniec palca, aby ochłodzić tylko swój język, lecz nawet to nie jest mu już dane. O wiecznym ogniu piekielnym pisze dość dokładnie św. Nikodem Hagioryta: »Wieczne oznacza to, 'co jest zawsze', co nigdy się nie kończy [...] Pamiętaj bracie mój, grzeszniku, o tej zawziętości, o tym jakim żarem uderzy w ciebie ogień gehenny. Pragnąc go przedstawić, Apostoł Paweł powiedział: jakże przerażające jest oczekiwanie sądu i żar ognia, który ma trawić opornych« (Hbr 10, 27)”. P. Gocko, op. cit., s. 11. 
A wtedy Pan spuścił na Sodomę i Gomorę deszcz siarki i ognia od Pana $<$ z nieba $>$. I tak zniszczył te miasta oraz całą okolicę wraz ze wszystkimi mieszkańcami miast, a także roślinność. Żona Lota, która szła za nim, obejrzała się i stała się słupem soli. Abraham, wstawszy rano, udał się na to miejsce, na którym przedtem stał przed Panem. I gdy spojrzał w stronę Sodomy i Gomory i na cały obszar dokoła, zobaczył unoszący się nad ziemią gęsty dym, jak gdyby z pieca, w którym topią metal. Tak więc Bóg, niszcząc okoliczne miasta, przez wzgląd na Abrahama ocalił Lota od zagłady, jakiej uległy te miasta, w których Lot przedtem mieszkał (Rdz 19,24-29).

\section{KATEDRA PLONIE - W KRĘGU GENEROWANYCH ZNACZEŃ}

Pożar katedry Notre Dame wywołał niezliczone reakcje w mediach - w tym także w mediach społecznościowych. Tradycyjnie w portalu Facebook zaroiło się od zdjęć - nie tylko płonącej budowli, ale i wspomnieniowych zdjęć własnych użytkowników, którzy mieli wcześniej okazję zobaczyć katedrę na żywo, w całej jej krasie. Zwyczajowo prezentowanym obrazom towarzyszyły dodawane przez użytkowników opisy emocji i/lub emotikony reprezentujące smutek, wstrząs lub złość. Tego typu wpisy, podobnie jak „szerowanie” informacji o wydarzeniu w samych początkach „medialnej burzy”, mieszczą się w zwyczajowym savoir-vivrze mediów społecznościowych.

Co jest tutaj interesujące, to pojawiające się, zaledwie kilka godzin od ukazania się pierwszych informacji o pożarze, jego rozliczne, wspomniane już wcześniej, semiotyzacje. Na ich podstawie naszkicować można wybrane linie frontu konfliktów światopoglądowych. Z semiotycznego punktu widzenia uznać można, że quasi-transparentny język tradycyjnych mediów zastąpiony zostaje mnogością innych - komunikat wyjściowy zostaje zatem przekodowany, przy czym w nowych komunikatach zachowane zostaje jego jądro, natomiast za sprawą twórczego przekładu na nowe języki (J. Łotman) $)^{20}$

${ }^{20}$ Jurij Łotman stwierdza, że podstawą kreowania nowych znaczeń jest twórczy przekład, to jest taki, który sprawia, że z tekstu T1, po dokonaniu translacji, otrzymuje się taki tekst T2, że po ponownym akcie przekładu, tym razem znowuż na język tekstu T1, otrzyma się nie ścisłą odpowiedniość, lecz jedynie podobieństwo, a co za tym idzie - przyrost znaczenia. Ścisła odpowiedniość przekładu zachodzić może jedynie w językach formalnych. Dodatkowo tekst wyjściowy 
ujawniają się jego niezliczone znaczenia, konstruowane w owych tekstach. Wspomniane translacje i przekodowania mają nadto rozmaity charakter raz jest to nałożenie na komunikat wyjściowy nowych ram semiotycznych, właśnie poprzez użycie nowego języka (choćby - biblijnego), raz jest to przełożenie obrazu na słowa lub odwrotnie: słów na obraz. Wszystkie te przekodowania zyskują nadto dodatkowy, niezwykle istotny kontekst mediów społecznościowych. Wymuszają one syntezę, uproszczenie, „mocne akcentowanie", nierzadko również kontrowersyjny charakter, a także pewną swobodę wypowiedzi (ograniczoną, rzecz jasna, chociażby przez polityki poszczególnych portali, choć jednocześnie kontrowersyjne komunikaty nierzadko wymykają się algorytmizowanej cenzurze). Co istotne - komunikaty owe mają nierzadko charakter jawnie retoryczny i wpisują się w język danych „baniek informacyjnych”.

Pożar katedry został więc przejęty jako komunikat chociażby przez różnej proweniencji „konserwatystów”, ortodoksyjnych katolików czy, szerzej, przez tak zwaną prawą stronę Internetu, czyli użytkowników o pewnym szkicowym wspólnym zbiorze poglądów i wartości, do których zaliczyć można między innymi przywiązanie do tradycji, zaangażowanie religijne (na ogół antyekumeniczne, a także wykluczające dialog międzyreligijny, skoncentrowane również, w dużej mierze, na „religijności ludowej”, niejako spauperyzowanej oraz na sposób lokalny upolitycznionej), zaangażowanie w lokalność (i - w konsekwencji - swoiście pojmowany patriotyzm), niechęć wobec przemian kulturowych i wszelkiego rodzaju „Innych” (migrantów, przedstawicieli innych religii, mniejszości etnicznych, seksualnych etc.), poczucie zagrożenia zmianą, silną tożsamość etniczną, narodową, religijną, konfrontacyjny stosunek do rzeczywistości, w tym do „myślących inaczej” (jako „rozbijających system od środka”), czy w końcu apoteozę walki (głównie ideologicznej, przy czym w narracjach tego typu pojawiają się niezliczone przekodowania narodowo-wyzwoleńczych i religijnych narracji oporu, sprzeciwu i podboju - poprzez odniesienie do kategorii „przedmurza chrześcijaństwa” czy nawiązania do wojen religijnych i krucjat oraz mariażu „tronu z ołtarzem”, a także przez liczne odniesienia do wydarzeń

przekodowywany jest za pomocą nie jednego, lecz wielu kodów, co prowadzi do wytworzenia polisemantycznego nowego komunikatu. Zob. J. Łotman, Trzy funkcje tekstu, [w:] idem, Uniwersum umystu, op. cit., s. 72. 
i postaci historycznych, jak choćby bitwa pod Wiedniem, husaria, żołnierze wyklęci etc.). „Prawą stronę Internetu” można zatem przyporządkować (co będzie, rzecz jasna, pewną idealizacją i uproszczeniem) do tego modelu, który Marcin Napiórkowski określa mianem „toposu konduktu”21.

W tego typu przekodowaniach szczególnie intensywnie uwidacznia się biblijna rama semiotyczna - pożar deszyfrowany jest przez pryzmat „komunikatu od Boga”, mającego przy tym charakter przestrogi czy wręcz - kary. Ogień zyskuje więc wymiar symboliczny, a znaczenia mu przydawane stanowią przekodowania właśnie już wspomnianych biblijnych zasobów semiotycznych, jak choćby historia Sodomy czy przekazy zawarte w Apokalipsie. Zachodzi tu następujący łańcuch skojarzeń i symbolizacji: Notre Dame symbolizuje Paryż, Paryż symbolizuje Francję, Francja zaś projektowany „zgniły Zachód” (czyli tutaj: laicyzację, politykę multikulturową i promigracyjną, swobodę obyczajową etc.). Pożar katedry zatem odczytywany jest w tym kontekście jako kara zesłana na „nową Sodomę” i/lub ostrzeżenie przed podążaniem w tym samym kierunku - przy czym akcenty rozkładane są na różny sposób: raz jest to kara za porzucenie Boga, innym razem za dominującą rolę innowierców. Notre Dame w narracjach z tego zbioru symbolizuje też cywilizację europejską, która upada, gdyż dystansuje się od własnych (chrześcijańskich) korzeni i odcina od wiary, Boga i dziedzictwa kulturowego, pozwalając na stopniowe rozpuszczanie własnej tożsamości w globalnym braku wartości. Bóg zatem karze za grzechy, za odejście od prawdziwej wiary, ale i przestrzega przed innowiercami, którzy w tym kontekście oznaczają muzułmanów, gotowych „zdominować” Europę i, w tej optyce, doprowadzić do jej ostatecznego upadku (il. 1-4).

W komunikatach z tego zbioru ujawniają się zatem linie podziałów światopoglądowych i politycznych czy właśnie - projektowane linie frontu

${ }^{21}$ Marcin Napiórkowski rekonstruuje linię napięcia między „toposem Konduktu” a „toposem Pochodu”, gdzie pierwszy oznacza nieustanną aktualizację i zarazem mitologizację przeszłości oraz taką kontrolę nad narracjami historycznymi, która umożliwia budowanie możliwie najbardziej pozytywnego auto-wizerunku, drugi zaś „zamknięcie przeszłości” i dążenie naprzód. Zestawić pojęcia te można ze zbliżonymi kategoriami „tradycjonalistów” i „postępowców”; Zob. M. Napiórkowski, Powstanie umarlych. Historia pamięci 1944-2014, Warszawa 2016, s. 347. 


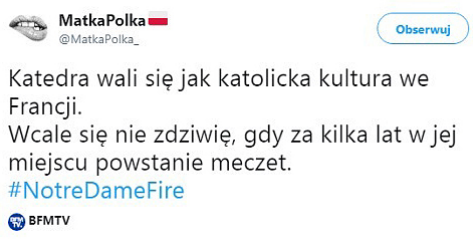

10. Archidiecezja Krakowska (irchKrakowska

Obserwuj

"Ta płonąca katedra to symbol płonącej Europy! - \#kardStanisławDziwisz w specjalnym oświadczeniu, wydanym w związku z wieczornym pożarem paryskiej katedry \#NotreDame.

\section{bit.ly/2KGvLyV}

\#notredameonfire \#Paryż

@EpiskopatNews @VaticanNews

@FRANCE24 @agencja_KAI

Il. 1-2. Wybrane twitty $z$ „prawej strony Internetu"

wojen kulturowych. Przebiegają one z jednej strony między „konserwatystami” a "postępowcami”, z drugiej zaś - między „Europejczykami” a, w tej optyce wrogim, "elementem napływowym”, „obcym kulturowo”, przy czym osią konfliktu ma tu być wiara religijna; byłby to zatem projektowany konflikt między „chrześcijanami” a „muzułmanami" (przy czym pojęcia te czy zbiory widziane są jako homogeniczne, o ograniczonej liczbie elementów charakterystycznych, a ich konstruowanie w rzeczonych komunikatach zorientowane jest na efekty retoryczne ${ }^{22}$ ). Przekodowania tego typu wpisują się zatem w szerszą semiotyczną ramę typowych dla „baniek informacyjnych” zasobów symbolicznych, konglomeratów wartości i norm, a także środków wyrazu, poetyk i retoryk.

Co ciekawe, pojęcia grzechu, winy i kary zostają również przekodowane w tych komunikatach, które produkowane są w zupełnie innej „bańce informacyjnej”, przez „postępowców”, czyli tych, którzy realizują, by ponownie użyć terminologii Napiórkowskiego, „topos Pochodu”. W wytwarzanych przez tę z kolei „bańkę” komunikatach na plan pierwszy wysuwa się antyklerykalizm - stąd też pożar katedry staje się symboliczną „karą za grzechy Kościoła”, który sprzeniewierzył się cnotom ewangelicznym. Tematyzowane są tutaj aktualne kwestie polityczne, etyczne i prawne, zwłaszcza te, które

${ }^{22}$ Jak zauważa Łotman: „Organizacja retoryczna powstaje w polu napięcia semantycznego pomiędzy strukturą »organiczną i $i$ cudzą", przy czym jej elementy podlegają tu podwójnej interpretacji. »Obca« organizacja, nawet mechanicznie przeniesiona do nowego kontekstu strukturalnego, przestaje być równa sobie i staje się znakiem lub imitacją samej siebie". J. Łotman, Retoryka - mechanizm generowania sensu, [w:] idem, Uniwersum umystu, op. cit., s. 116. Widziany z zewnątrz „obcy system” traktowany jest redukcjonistycznie, co wynika m.in. z założenia o ograniczonej liczbie jego elementów. 
wywołują największe społeczne emocje, jak problem pedofilii w Kościele, szczególnie intensywnie dyskutowany w mediach i wywołujący reakcje daleko przekraczające ramy slaktywizmu (chociażby akcja Baby Shoes Remember ${ }^{23}$ ). Niektóre komunikaty tego typu wytwarzane są z pozycji „reformatorskich” dominuje w nich retoryczny kontekst „powrotu do źródel”, do cnót ewangelicznych, wezwanie do żalu za grzechy, do zadośćuczynienia i samooczyszczenia Kościoła. W tych przypadkach kodowanie quasi-biblijne jawi się jako spójne z konkretnym światoobrazem. Są jednak i takie komunikaty, które tworzone są z pozycji całkowitego dystansu wobec systemu religii i zjawiska wiary w przeciwieństwie do tych pierwszych dominuje tu symbolika ognia nie jako ostrzeżenia i nawołania do zmiany, lecz nieodwracalnej kary za grzechy, potępienia. Przekodowywanie quasi-transparentnych komunikatów medialnych za pomocą odniesień biblijnych z jednej strony czytać można jako metakomentarz i zarazem translację na język bliski

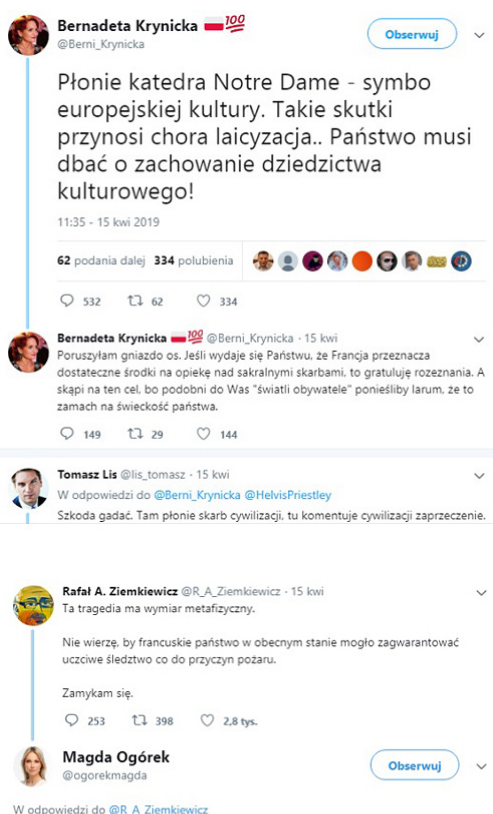

Pod posadzką korona cierniowa Chrystusa. Za 4 dni Wielki Piątek. Woda już na pewno zalała skarbiec, gdzie spoczywa relikwia.

Za to za rok w okolicy na pewno przybędzie nowy meczet.

Siedzę przed tv zdruzgotana.

12:14 - 15 kwi 2019

216 podarn dalej 1407 polubieñ

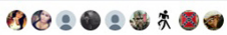

Il. 3-4. Wybrane twitty z „prawej strony Internetu"

${ }^{23}$ Zob. https://www.rp.pl/Kosciol/180829499-Buciki-na-kosciolachAkcja-upamietnia-ofiar-pedofilii.html [dostęp: 5.09.2019]; http://wyborcza. pl/7,75398,23827676,dzieciece-buciki-na-murach-kosciolow-polska-upamietnia -ofiary.html [dostęp: 5.09.2019]; https://www.tvn24.pl/wiadomosci-z-kraju,3/ buciki-przed-kosciolami-druga-odslona-akcji-baby-shoes-remember,963927.html [dostęp: 5.09.2019]. 


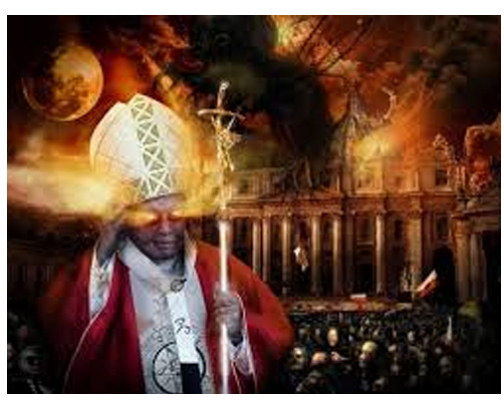

Il. 5. Krysztofiak: blog globalny, przedstawienie Antychrysta

projektowanemu rzekomemu odbiorcy ${ }^{24}$, z drugiej zaś - jako przykład na to, że tekst kanoniczny służy wciąż za źródło istotnych kulturowych słowników i gramatyk oraz rezerwuar podstawowych zasobów symbolicznych konkretnej formacji kulturowej. Można też widzieć tego typu komunikaty jako reaktywne względem wskazanych powyżej tekstów apokaliptycznych, dostrzegając tym samym ich ironiczny i subwersywny względem „wrogiej bańki” charakter.

Doskonałym egzemplum dla tego typu komunikatów jest wpis na blogu „Krysztofiak: blog globalny”. Autor w sposób dosadny zrównuje Kościół z Antychrystem, choć czyni to z pozycji dystansu, jedynie pasożytując na chrześcijańskiej symbolice i słowniku, dodatkowo okraszając tekst wymowną grafiką (il. 5), przedstawiającą papieża (Jana Pawła II) jako właśnie Antychrysta:

Ogień i pożar w symbolice chrześcijańskiej symbolizują akt „wypalania Antychrysta” z ludzkiej duszy. Ogień w Notre Dame stanowi więc apel Boga do wiernych, aby wypalili Antychrysta ze swojego Kościoła. Z tego punktu widzenia, Bóg mówi katolikom, iż w Kościele usadowił się Antychryst.

Skoro Katedra Notre Dame jest jednym z najważniejszych miejsc kultu chrześcijańskiego w Europie, to jej pożar może być rozumiany jako boska wskazówka mówiąca o miejscu, w którym Antychryst zadomowił się w Kościele.

${ }^{24} \mathrm{Z}$ jednej strony ów projektowany odbiorca czy, mówiąc w języku Eco, „czytelnik modelowy” sam traktowany jest jako przedstawiciel Kościoła, chociażby przez fakt bycia członkiem wspólnoty religijnej, z drugiej zaś - jest to „odbiorca rzekomy”, bo komunikaty wytwarzane w obszarze mediów społecznościowych często zwrócone są do odbiorcy z danej „bańki informacyjnej”, wyznającego podobne poglądy, wartości, style życia etc. O tym zatem, czy ów „czytelnik modelowy” jest „odbiorcą rzekomym”, czy „faktycznym”, decyduje w dużej mierze miejsce umieszczenia komunikatu - we własnej „bańce” ma on zdecydowanie mniej subwersywny charakter, niż opublikowany w medialnych przestrzeniach obcych „baniek”, gdzie funkcjonuje jako tekst-prowokator. 
Bóg mówi, że Antychryst zawładnął Kościołem katolickim w jego najważniejszym miejscu, w samym sercu - czyli w Watykanie i w episkopatach. Bóg mówi wiernym, iż Antychryst zawładnął duszami papieża, arcybiskupów, biskupów i kapłanów. Pożar w Notre Dame można więc ostatecznie rozumieć jako apel samego Boga, nawołujący wiernych do „alegorycznego spalenia na stosie" hierarchów obecnego Kościoła. Godząc się na pożogę w Notre Dame, Bóg wydaje się apelować do wiernych, aby odeszli od swoich pasterzy, aby zauważyli Antychrysta w ich duszach i aby podjęli z nim walkę; aby usłyszeli głos Antychrysta w słowach abp Jędraszewskiego, abp Gądeckiego, ks. Rydzyka i innych katolickich dygnitarzy ${ }^{25}$.

W podobnym tonie, przekodowując - w poetyce bliskiej językom hermetyzmu - prócz biblijnej symboliki ognia również języki astrologii, wypowiedziała się na Facebooku Manuela Gretkowska:

W średniowieczu na tamtejszym uniwersytecie wykładano astrologię. Gwiazdy o 18.50 kiedy wybuchł pożar były „gorące” dla paryskiego Nieba. W znaku Koziorożca zacieśnia się koniunkcja złowieszczego Saturna z echem Marsa (Plutonem nieznanym epoce). Ta koniunkcja przynosząca zniszczenia jest jak kleszcze, zanurzone w żywioł ognia Barana, wiosennego Słońca. Do tego kwadratury sprzyjające katastrofom trudnym do wyobrażenia. [...]. Notre Dame zbudowano prawie tysiąc lat temu zgodnie z masońską sztuką i symboliką chrześcijańską. Dach jest symbolem miłosierdzia, od niego zaczął się pożar. Mury - jednością dusz, laickich i kleru. Może w tym leży „przyczyna”, w nieudanej renowacji, remoncie Kościoła. Bóg niszczy swoje dzieło, powiedziano by w średniowieczu, za karę. Za pedofilię, brak miłosierdzia i pychę kleru. Sypie się Watykan, płonie Notre Dame ${ }^{26}$.

Apokaliptyczne deszyfracje, zarówno związane z religijnymi czy quasi-religijnymi odczytaniami pożaru w kategoriach ostrzeżenia czy kary, jak i niepowetowanej straty dla kultury europejskiej i jej dziedzictwa, w połączeniu z późniejszymi realnymi działaniami na rzecz odbudowania katedry, stały się, na zasadzie nieograniczonej semiozy, kolejnymi znakami. Odczytanie

${ }^{25}$ Krysztofiak: blog globalny; https://krysztofiak-wojciech.blogspot.com /2019/04/pozar-w-notre-dame-jako-hierofaniaczy.html [dostęp: 6.09.2019].

${ }^{26}$ https://www.facebook.com/gretkowska.manuela/posts/2222652697827274 [dostęp: 6.09.2019; pisownia oryginalna]. 


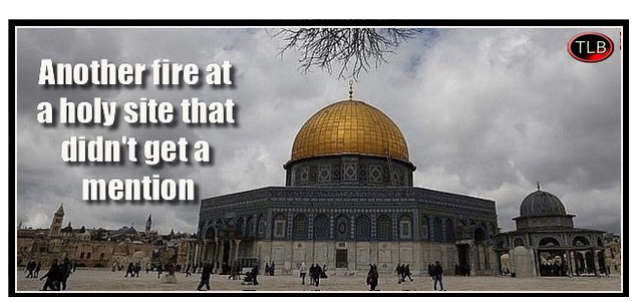

Il. 6. Mem tematyzujący kwestię eurocentryczności przekazów medialnych tych znaków i umieszczenie ich we „wreszcie właściwym kontekście" stanowi punkt wyjścia dla kolejnych komunikatów o charakterze mocno retorycznym, wpisujących się w pewien określony porządek wartości i określoną wizję świata oraz człowieka. Co ciekawe, owe semiotyzacje drugiego rzędu

równie chętnie odnoszą się do poetyki apokaliptycznej i wizji Armagedonu, choć niebezpieczeństw czy groźby „końca dziejów” upatrują zgoła gdzie indziej niż wcześniej wspomniani „apokaliptycy konserwatywni”. Zatem kolejne teksty, wytwarzane na podstawie wcześniejszych komunikatów -znaków, mają charakter krytyczny. Retoryczne ostrze skierowane zostaje między innymi w stronę postawy eurocentrycznej - wskazuje się tutaj niewspółmierność reakcji na pożar w stosunku do kataklizmów i nieszczęść wydarzających się w innych częściach świata, które pozostają poza obszarem zainteresowania „egotycznej Europy”, jej elit, mediów, a tym samym - całych społeczeństw. Doskonałą okazją do wypunktowania tego problemu stał się inny pożar, który wybuchł w podobnym czasie, co pożar katedry Notre Dame - pożar meczetu Al-Aksa w Jerozolimie. Lekceważenie tej informacji lub jedynie minimalna ilość czasu antenowego czy przestrzeni medialnej poświęconych temu wydarzeniu sprowokowały zatem powstanie kolejnych komunikatów, mniej lub bardziej bezpośrednio odnoszących się do pożaru Notre Dame i jego medialnej nośności (il. 6).

Jak wskazuje Weronika Rokicka, nie tylko pożar jerozolimskiego meczetu umknął uwadze Europy lub został przez nią zlekceważony: „Co łączy niedawny cyklon w Mozambiku, śmierć uczniów w ataku talibów w Afganistanie i zabójstwo indyjskiej dziennikarki Gauri Lankesh? To, że z polskich mediów się o nich niewiele dowiemy"27. Rokicka podaje także inne przykłady zjawiska - gdy w styczniu 2015 roku cała Europa żyła zamachami

27 W. Rokicka, Europaplaczenad katedra Notre Dame, co wiemyo innych wydarzeniach na świecie?, „Krytyka Polityczna”, 20 kwietnia 2019; https://krytykapolityczna. $\mathrm{pl} /$ swiat/europa-placze-nad-katedra-notre-dame-co-wiemy-o-innych-wydarze- 
w paryskiej redakcji „Charlie Hebdo”, w Baga w Nigerii ekstremiści religijni dokonali masakry, w której zginęły dwa tysiące osób. Drugie z przywołanych wydarzeń praktycznie nie pojawiło się w europejskich, w tym polskich, mediach. Punktowanie wspomnianej przez autorkę obojętności stanowi punkt wyjścia do krytycznego namysłu nie tylko nad wspomnianym eurocentryzmem, ale również nad mediami i sterowalną reaktywnością Internetu.

Pożar meczetu wywołał także reakcje "prawej strony Internetu”, przy czym te

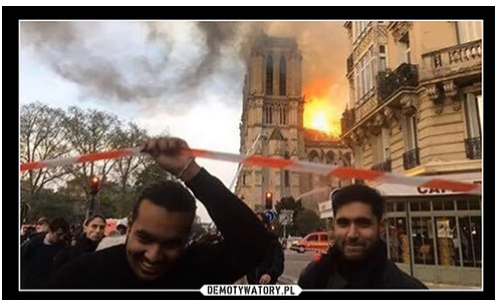

Muzułmanie śmiali się z pożaru Katedry Notre Dame

W tym samym czasie palił się meczet Al Aksa w Jerozolimie. A to peszek.

Il. 7. Sarkastyczny backlash $w$ reakcji na rzekoma "radość innowierców" w związku z pożarem katedry (Demotywatory.pl) utrzymane były w tonie raczej agresywnym i/lub sarkastycznym (il. 7), odnosząc się do rzekomych pozytywnych, radosnych reakcji „muzułmanów” (kategoria ta jest tu, rzecz jasna, nieostra, wyjątkowo pojemna i zorientowana retorycznie na budowanie idei konfliktu między „światem chrześcijańskim” a „światem islamu”, przy wspomnianym już powyżej traktowaniu obu tych konstruktów jako homogenicznych oraz ograniczonej liczbie charakterystycznych elementów zbioru).

Co ciekawe, w sieci pojawiły się również reakcje na tego typu komunikaty - przykładowo Ośrodek Monitorowania Zachowań Rasistowskich i Ksenofobicznych umieścił na swoim facebookowym profilu następujące zestawienie (il. 8) (przy czym nie jest jasne, czy osoby reagujące emotikonem „śmiech” na paryskie wydarzenia traktowane są tu apriorycznie jako muzułmanie, co byłoby, rzecz jasna, delikatnie mówiąc - nieuprawnione).

OMZRiK poprzedza grafikę wpisem odnoszącym się bezpośrednio do wspomnianych już apokaliptycznych odczytań pożaru i deszyfracji, mających na celu budowanie linii napięć i konfliktów między przedstawicielami różnych religii:

niach-na-swiecie/?fbclid=IwAR1se7TSsrWjjSwvK7RbYSkWX4qO_7lQdX4CmU EUUtx4jIoP3khnYsc5mVw [dostęp: 6.09.2019]. 


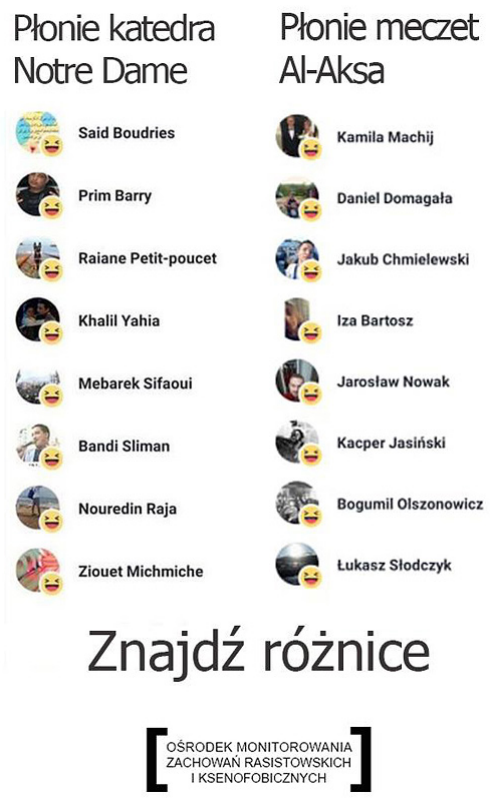

Il. 8. Reaktywny komunikat odnoszacy się do wcześniejszych semiotyzacji czynionych w poetyce "wojny kulturowej” (Ośrodek Monitorowania Zachowań Rasistowskich i Ksenofobicznych)

W tym samym czasie, gdy płonęła katedra Notre Dame w Paryżu wybuchł pożar w meczecie Al-Aksa w Jerozolimie, jednym $\mathrm{z}$ najświętszych miejsc dla muzułmanów.

Ciekawe czy muzułmanie także alarmują, że to na pewno katolicy podpalili, a na jego miejscu pojawi się zaraz kościół katolicki? Bo np. na stronach Młodzieży Wszechpolskiej roi się od takich teorii.

I czy muzułmanie mają swojego „ministra Andruszkiewicza”, który widzi w pożarze meczetu „symbol upadku islamu"? ${ }^{28}$

Reaktywne komunikaty, stanowiące odczytanie wcześniej przywołanych tekstów jako znaków, problematyzują jednak również inne kwestie. Wychodząc od semiotyzacji pierwszego rzędu, używając nadto nierzadko podobnych kodów, wskazują na, w tej optyce prawdziwe, sygnały zbliżającego się końca świata, na faktycznych „jeźdźców apokalipsy”, punktując przy tym retorycznie ślepotę ludzkości w odniesieniu do owych prawdziwych zagrożeń. Wskazuje się tu również na nierównowagę sił, środków i atencji lokowanych w walce z faktycznymi globalnymi problemami w porównaniu do „eurocentrycznych błahostek", takich jak pożar paryskiej katedry.

I tak głównym punktem zainteresowania stają się kwestie środowiskowe, ekologiczne, oraz problemy związane z globalnym ociepleniem. Pożar Notre Dame daje wyjątkową okazję do produkowania retorycznie zorientowanych, zaangażowanych komunikatów, można go bowiem (oraz - reakcje nań) zestawić z wielkimi pożarami syberyjskich i amazońskich lasów (il. 9-10).

28 https://www.facebook.com/osrodek.monitorowania/posts/953909964784137 [dostęp: 6.09.2019; pisownia oryginalna]. 


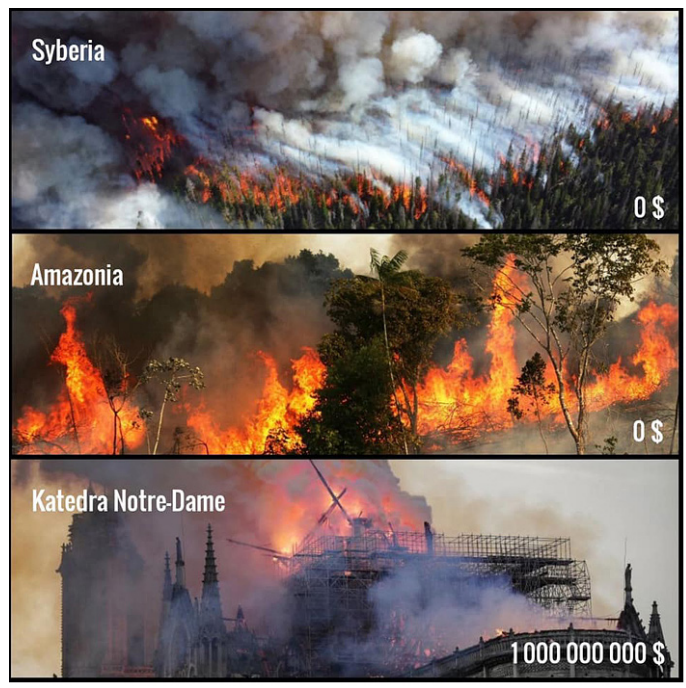

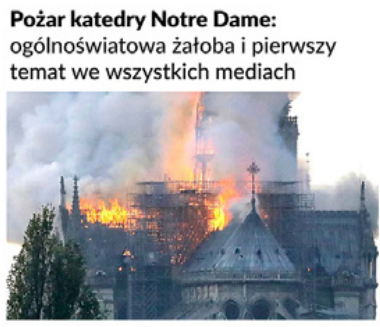

Liczne, ogromne pożary w Amazonii: media zainteresowały się dopiero gdy dym dotarł nad São Paulo

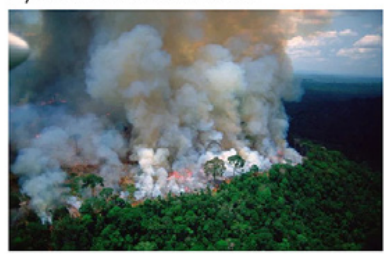

Il. 9-10. Zaangażowane, zorientowane retorycznie komunikaty, wykorzystujące medialność pożaru Notre Dame do zwrócenia uwagi na istotniejsze, z punktu widzenia ich twórców, problemy

W mediach społecznościowych pojawiały się niezliczone komunikaty problematyzujące tę kwestię, których doskonałym egzemplum może być chociażby wpis jednego z użytkowników Facebooka:

Amazonia płonie. Świat milczy!! Gigantyczne pożary widać z kosmosu. Dym zasnuł Sao Paulo - największe miasto Brazylii

Kiedy spłonął Notre Dame, ogłoszono tragedię na świecie, a w ciągu kilku dni zebrano 218 milionów euro, aby go odbudować.

Od kilkunastu dni płonie Amazonia, płuca świata, kolebka różnorodności biologicznej i nikt nie robi nic, ani media, ani rządy ${ }^{29}$.

Warstwa tekstowa wzmocniona zostaje nadto przez warstwę wizualną do wpisu dołączone jest zdjęcie, przedstawiające małpią matkę z martwym dzieckiem na tle przypominającym łunę bijącą od płonących lasów (il. 11). Przejmująca fotografia przywodzi na myśl pietę, kojarząc się również ze

29 https://www.facebook.com/iwona.kopacz2/posts/2314503568596931 [dostęp: 6.09.2019; pisownia oryginalna]. 


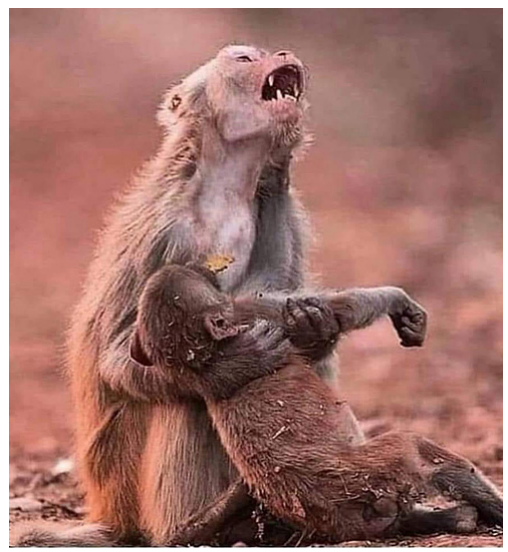

Il. 11. Viralowe i wykorzystywane w celach retorycznych zdjęcie indyjskich matp

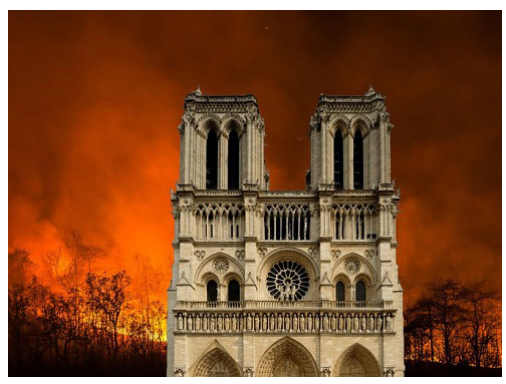

Il. 12. Ironiczny kolaż ukazujacy „desperację amazońskich lasów", które, by zwrócić na siebie uwage, „wybudowaty sobie katedrę" („ASZ Dziennik”)

zdjęciami z obszarów ogarniętych wojną, przedstawiającymi zrozpaczone matki opłakujące swe umierające dzieci. Strona wizualna obliczona jest więc na wywołanie konkretnych emocji u odbiorcy, na poruszenie go. Co jednak ciekawe, małpki widoczne na zdjęciu zostały sfotografowane w Indiach, a małpie dziecko, jak poinformował fotograf, bynajmniej nie zmarło, lecz jedynie - upadło.

Zestawianie ze sobą wspomnianych wydarzeń i reakcji na nie przyjmuje jednak również bardziej ironiczny, szyderczy czy ludyczny charakter. Przykładem może być wpis twórców „ASZ Dziennika”, profilu o charakterze satyrycznym, w którym poszczególne posty stylizowane są na artykuły z prasy codziennej, nierzadko brukowej. $\mathrm{Na}$ profilu znajdujemy więc „artykuł” pod tytułem Desperacja lasu w Amazonii. Zbudowat sobie katedre Notre Dame, żeby świat przejął się pożarem, w którym czytamy: „Piękna gotycka archikatedra pojawiła się w nocy ze środy na czwartek w sercu Ameryki Południowej - podaje »Reuters«. To kolejna desperacka próba zwrócenia na siebie uwagi przez las deszczowy z Amazonii, który trawiony jest przez pożar" ${ }^{\prime 30}$. Do tekstu dołączona jest grafika - fotomontaż przedstawiający katedrę na tle płonącego lasu (il. 12).

${ }^{30}$ https://aszdziennik.pl/127335,desperacja-lasu-w-amazonii-zbudowal-so bie-katedre-z-notre-dame-zeby-ktos?fbclid=IwAR1DZ71KKXkUm8wlJWYZjj drcxEX71398oKoOBqk5s5Kxu4gwYiPHtvlH3g [dostęp: 6.09.2019]. Tekst i grafika dostępne również na profilu facebookowym „ASZ Dziennika”. 
Tekst „ASZ Dziennika” jest, rzecz jasna, komunikatem zaangażowanym, retorycznie nastawionym na podkreślanie niewspółmierności uwagi i środków inwestowanych w pomoc w sytuacjach, które są, pod względem faktycznego kataklizmu, nieporównywalne. Podobnie jak inne komunikaty tego typu i ten wykorzystuje nośność pożaru Notre Dame, by zwrócić uwagę na te kwestie, którym, zgodnie z optyką tekstu, nie poświęca się należytej uwagi, a które wymagają natychmiastowej reakcji i nadzwyczajnych działań.

W sieci znaleźć jednak można również mnogość komunikatów o stricte ludycznym charakterze, typowych dla folkloru internetowego i subwersywnych względem wszelkich tekstów zaangażowanych. Magdalena Kamińska o memach pisze tak:

Postrzegane z perspektywy cyberspołecznej memy okazują się czymś znacznie więcej aniżeli tylko łatwymi do zlekceważenia „śmiesznymi obrazkami z internetu". Formują popularną, szeroko dostępną i mobilną platformę do publicznego dyskutowania na temat spraw choćby jedynie przelotnie istotnych dla „cyberludu”. [...] Memetyczną twórczość można zinterpretować również jako formę przyczynkarskiego zapisu ważnych momentów życia społecznego w internecie, a same memy uznać za świadectwa zjawisk i wydarzeń, które anonimowi użytkownicy uznali za wystarczająco istotne [...]. W Sieci można odnaleźć praktycznie wszystkie odmiany humoru znane ze świata offline (oraz kilka mu nieznanych), lecz szczególną uwagę wśród nich zwracają te teksty, które mają charakter kontrowersyjny, prowokujący, agresywny, wulgarny, obraźliwy, a nawet okrutny. [...] Powinny być [one] traktowane jako charakterystyczne dla humoru internetowego, przy czym na uwagę zasługuje zwłaszcza fakt, że ich krytyczne ostrze uderza nie tylko w zjawiska ze świata offline, ale również w czysto internetowe fenomeny i praktyki ${ }^{31}$.

Memy powstałe w związku z pożarem katedry mogą być czytane jako reaktywne komunikaty mające wprowadzić element karnawalizacji w obszar nadmiernej powagi innych tekstów - powszechnej żałoby, medialnego szumu, nośności tematu, a w końcu także wspomnianych powyżej rozlicznych odczytań wydarzenia w kategorii tajemnego komunikatu, znaku czy symbolu. Memy rozsadzają „poetykę powagi” i grają z konwencjami

${ }^{31}$ M. Kamińska, Memosfera. Wprowadzenie do cyberkulturoznawstwa, Poznań 2017, s. 38-39. 


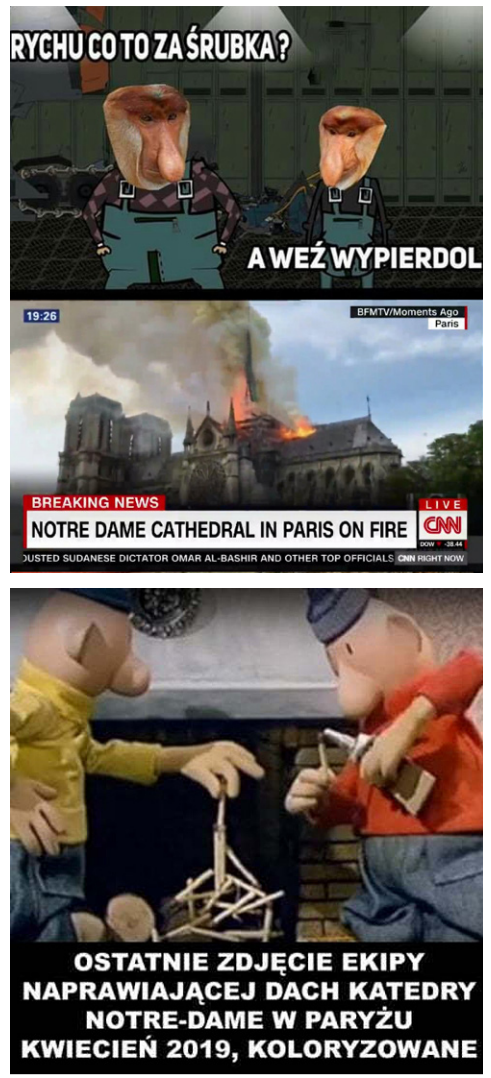

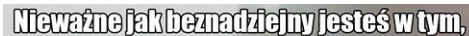

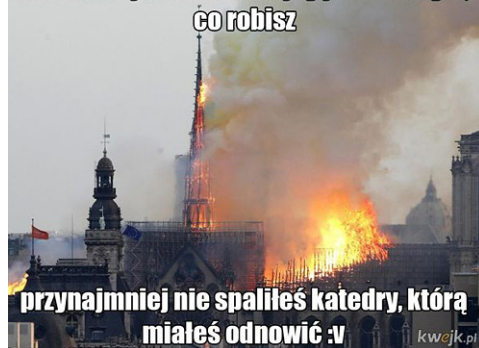

Il. 13-18. Przykłady netolore'u subwersywnego wobec zaangażowanych narracji rozmaitych „baniek informacyjnych” (Wykop.pl, Besty.pl, Joemonster.org, Kwejk.pl)
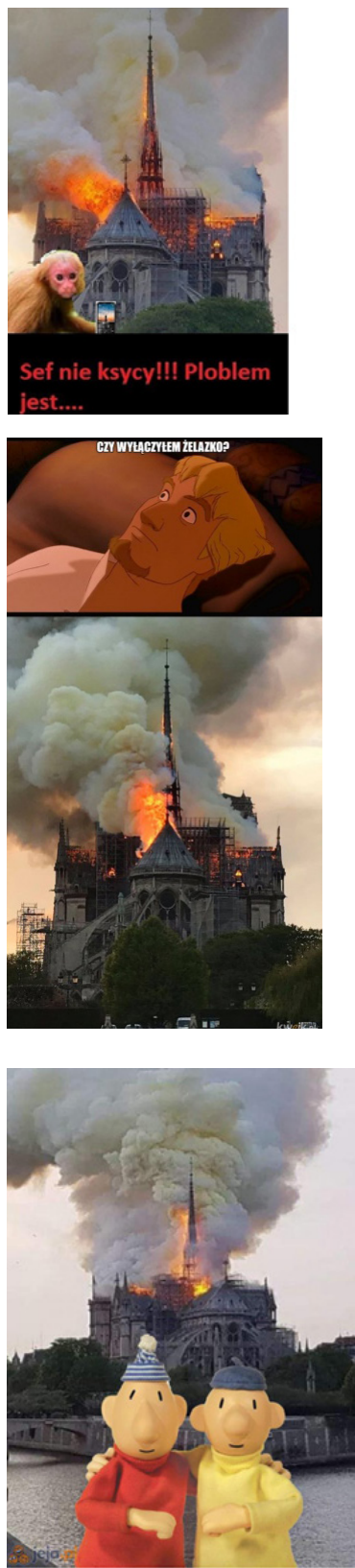
poprzednich przekodowań, jednocześnie używając właściwych sobie środków wyrazu, klisz i kodów, obecnych w innych, wcześniejszych tekstach tego gatunku - wykorzystują zatem nie tylko typowy język, nie tylko specyficzny humor, ale i całe serie powszechnie rozpoznawalnych memów wraz z ich estetykami. Stąd też poczesne miejsce zajmują tu memy z nosaczem sundajskim, prześmiewczą figuracją Polaka, czy z małpką z gatunku uakari szkarłatny, reprezentującą Ukraińca - oscylują one wokół projektowanych w niezliczonych wcześniejszych memach tego typu „cech narodowych” oraz „działalności zarobkowej na emigracji”, głównie w charakterze pracownika fizycznego na budowie, co, rzecz jasna, idealnie komponuje się z głównym tematem memu, czyli remontem katedry, w trakcie którego wybuchł pożar (il. 13-18). Mamy tu zatem do czynienia z treściami prześmiewczymi przede wszystkim względem metafizycznych odczytań zdarzenia jako rzekomego znaku od Boga, kary za grzechy: Armagedon, symbol upadku Europy czy chrześcijaństwa ma być de facto efektem działania niezbyt rozgarniętego gastarbeitera, reagującego na katastrofę w sposób rozczulająco nieporadny i jakby nie zdającego sobie sprawy - no właśnie - z powagi sytuacji (w sieci krąży nadto pasta - typowo internetowy gatunek para-literacki - w podobny sposób wyjaśniająca przyczyny pożaru ${ }^{32}$ ).

$32>$,idziesz ulicą

$>$ jakaś laska 9/10 ci macha

$>$ nie wiesz skąd ją znasz, ale jest ładna

$>$ więc odmachujesz

>za kilka sekund ogarniasz, że macha typowi, który stoi za tobą

>aby jakoś wyjść z niezręcznej sytuacji nadal machasz

$>$ możesz udawać, że łapiesz taksówkę

$>$ taksówka podjeżdża, więc wsiadasz

$>$ kierowca pyta gdzie jedziemy

>pierwsze co ci przychodzi do głowy

$>$ lotnisko

$>$ taksówkarz wiezie cię na lotnisko

$>$ wysiada razem $\mathrm{z}$ tobą, bo chce zapalić

$>$ musisz udawać, że na kogoś czekasz

$>$ stoicie obok siebie, czujesz jego wzrok

$>$ bez walizeczki na lotnisko? na kogoś pan czeka?

$>$ nie odzywasz się 
Ironiczny względem rozmaitych religijnie warunkowanych deszyfracji jest chociażby mem ukazujący w dymie, unoszącym się z płonącej katedry, wielkiego nosacza-Polaka (il. 19), co jest żartem bazującym nie tylko na wspomnianych wcześniejszych odczytaniach metafizyczno-mistyczno-religijnych,

>na kogo? no kurwa na nikogo, zapłaciłeś właśnie trzy dychy, żeby nie wyjść na debila

>ale teraz wyszedłeś na niego podwójnie

$>$ aby temu zaradzić wpadasz na pomysł

$>$ więc odpowiadasz

>a no bo ja tak podróżuje po świecie, spontaniczne wyjazdy, przygody, szukam wrażeń, wróciłem tydzień temu z belize

$>$ głupi taksówkarz nawet nie wie co to

$>$ ooooo uuuuu panie

>gasi papierosa i odpala kolejnego, skurwysyn

$>$ a tera gdzie?

>dostajesz już kurwicy, ale ze stoickim spokojem odpowiadasz

$>$ tam gdzie wiatr poniesie

$>$ taksówkarz kiwa ze zrozumieniem głową udając, że rozumie i wyrzuca świeżo odpalonego peta

>podaje mi rękę

$>$ jestem sławuś. Panie, pan mi z nieba spadł

$>$ co tym kurwa razem

$>$ niech mnie pan zabierze ze sobą w świat, ja chce coś zmienić w życiu, żona i tak mnie nie kocha, bachory na studiach i mają mnie w dupie

$>$ w innej sytuacji zrobiłoby ci się przykro, ale teraz jesteś do granic możliwości wkurwiony

$>$ bo najdalej od domu to byłeś w Łebie na zielonej szkole

$>$ ale nie możesz się już wycofać

$>$ wzdychasz ciężko i sprawdzasz najbliższe loty

$>$ Paryż

$>$ no dobra, w sumie nie jest tak źle

$>$ razem ze sławusiem kupujecie bilety na samolot i lecicie, mając przy sobie tylko najważniejsze rzeczy

$>$ i kilkanaście paczek najtańszych petów sławusia, jest nałogowym palaczem i nawet tobie wcisnął kilka na przechowanie

>w Paryżu jest zajebiście 
ale i nawiązującym do watykańskiego dymu oraz słynnych „mistycznych” interpretacji wydarzeń z pogrzebu Jana Pawła II, gdzie zjawisko naturalne (wiatr przewracający karty Biblii złożonej na trumnie) został zdekodowany przez pryzmat wydarzenia nadnaturalnego, znaku. W końcu również, być może, przekodowana zostaje tutaj historia krzewu gorejącego, ognia jako symbolu Boga.

W grupie memów prześmiewczych znaleźć można również komunikaty wysoce interteksualne, używające mnogości kodów - nie tylko bazowego języka memów, ale i literatury, popkultury, przekodowanych tekstów z obszaru polityki, nierzadko już wcześniej przepuszczonych przez filtr netlore'u, polisemanycznie i wielowarstwowo ironicznych - mamy tu więc do czynienia z dzwonnikiem z Notre Dame w wydaniu disneyowskim czy zdjęciem Jerzego Urbana w przebraniu biskupa, znajdziemy również żarty z relikwii, tematyzujące kwestie wiary religijnej i faktycznej wartości dziedzictwa kulturowego, będące jednocześnie wyjątkowo swobodnymi, ironicznymi wariacjami na tematy kanoniczne (il. 20-22).

>nie wierzysz, że taka życiowa przygoda trafiła ci się tylko dlatego, że chciałeś nie wyjść na debila przed jakąś laską

>i nigdy byś nie pomyślał, że pięćdziesięcioletni taksówkarz może być takim świetnym towarzyszem

$>$ tylko to jego nałogowe palenie i fakt, że często zasypia w trakcie tej czynności >trochę się obawiasz, że sławuś kiedyś wznieci pożar

$>$ mniejsza o to

>jutro idziecie zobaczyć katedrę notre dame, to będzie dopiero coś!”. https://www.facebook.com/permalink.php?story_fbid=2027198004248665 \&id=1979581615676971 [dostęp: 6.09.2019]. 


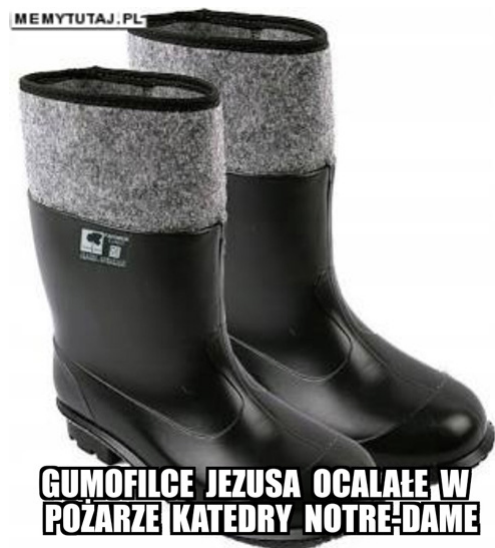

Il. 20-22. Wysoce intertekstualne prześmiewcze komunikaty, tematyzujace nie tylko pożar i jego liczne semiotyzacje, ale i katedrę jako historyczny tekst kultury (Wykop.pl, Besty.pl, Memytutaj.pl)
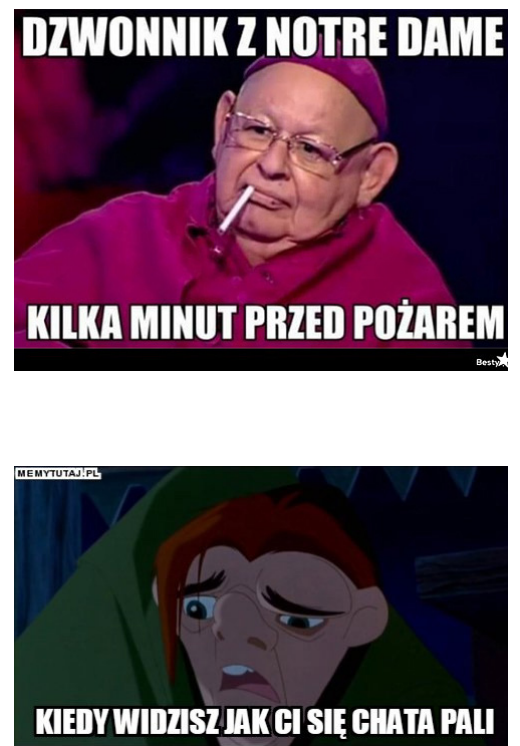

W sieci znaleźć można w końcu również memy autotematyczne - humor opiera się tu jednak nie tylko na nawiązaniach do internetowego folkloru, ale i na problematyzowaniu zjawiska infotainment oraz medialnej nośności wydarzeń, w tym zdolności mediów do całkowitego skupiania uwagi na jednej informacji (a więc także - do kreowania społecznych emocji i potrzeb, do zarządzania uwagą, do definiowania tego, co ważne i nieważne). Memy ironicznie przekodowują również teorie spiskowe, doprowadzając do absurdu zjawisko semiotyzacji wydarzeń i ich deszfracji, przy czym stawiane tezy (ujmowane w specyficznej retoryce o ugruntowanej już historii w obszarze twórczości internetowej - rodzaj grafiki, czcionki, sposób konstruowania pytania przewodniego, celowe błędy językowe) są wysoce abstrakcyjne (il. 23-24).

Memy zatem pozostają subwersywnym, ironicznym komentarzem do zbiorowych emocji, „medialnego szaleństwa” oraz rozmaitych, również internetowych, kontekstualizacji, semiotyzacji i interpretacji wydarzeń. Jak zawsze w obliczu medialnie zapośredniczonych i nagłośnionych faktów znaczących, kataklizmów, tragedii i momentów historycznych, budują one przestrzeń karnawalizacji, wytchnienia, z jednej strony ujścia dla zbiorowych 


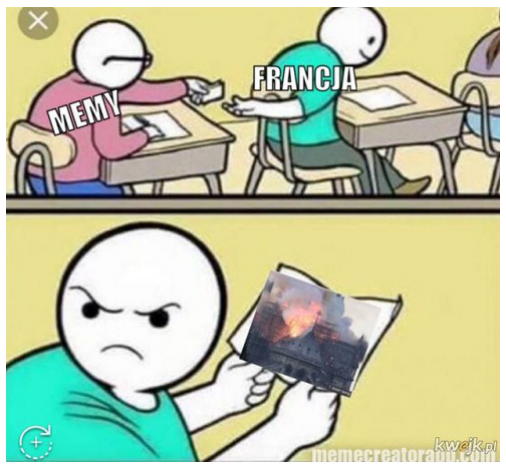

Il. 23-24. Memy autotematyczne (Kwejk.pl)

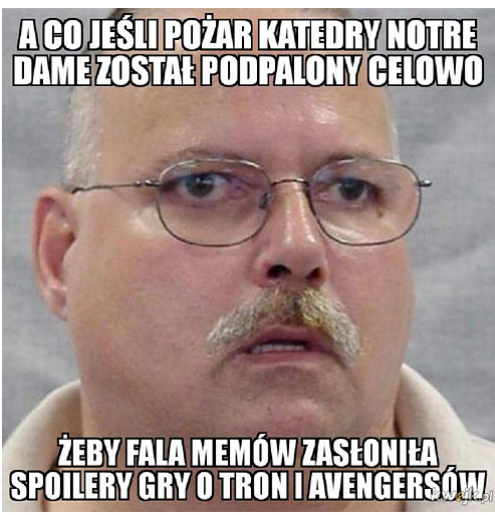

emocji, z drugiej zaś - ich krytyki, swego rodzaju zdystansowanego namysłu, wręcz (auto)krytyki kulturowej czy społecznej.

\section{PODSUMOWANIE}

Jak zauważa Wojciech J. Burszta, wojny kulturowe nie są zjawiskiem przebrzmiałym, a wręcz przeciwnie - w zmiennych, elastycznych, płynnych czy dynamicznych warunkach kulturowych nabierają mocy:

W głębszym sensie wojny kulturowe są permanentnym stanem napięcia między tradycyjnym i ponowoczesnym sposobem rozwiązywania problemów moralnych; wojny kultur, słowem, toczą się w rejestrze moralności i dotyczą nie tyle kwestii materialnych (zarobki, praca, rola państwa), ile konfliktów związanych z porządkiem normatywnym życia społecznego i kwestią tożsamości zbiorowych. Przyjęło się ten obszar nazywać wartościami postmaterialnymi. Tym samym - ostatecznie - gra idzie o opowiedzenie się za określoną wizją społeczeństwa i jego moralnych obligacji. Dlatego nietrudno się domyślić, że fronty bitewne moralnie fundowanych sporów o wartości dotyczą w istocie niemal wszystkich aspektów życia zbiorowego i indywidualnych wyborów aksjologicznych ${ }^{33}$.

33 W.J. Burszta, Kotwice pewności. Wojny kulurowe z popnacjonalizmem w tle, Warszawa 2013, s. 130. 
Fronty wojen kulturowych („tradycjonaliści” versus „postępowcy”, „patrioci” versus „internacjonaliści”, „konserwatyści” versus „liberałowie”, „[pop]prawica” versus „[pop]lewica”) znajdują zatem częściowe odzwierciedlenie (a także - napęd, inspirację) w internetowych „bańkach informacyjnych", w ich językach, przestrzeniach etc. Walki na tych frontach (a jest ich wiele, granice bowiem przebiegają różnie, a osobne zbiory nierzadko mają części wspólne) toczą się nie tylko o wizję społeczeństwa, człowieka, świata, nie tylko o wartości i normy, ale również - o zasoby symboliczne. Wokół rozmaitych wydarzeń, informacji i zjawisk narastają więc konflikty odczytań, będące punktem wyjścia do kolejnych bitew czy potyczek, realizujących retoryczne cele stron konfliktu.

Nagłośniony medialnie pożar katedry Notre Dame stał się, jak wskazano, takim właśnie punktem wyjścia dla niezliczonych, warunkowanych światopoglądowo odczytań i interpretacji, stanowiących kolejne elementy wojennej mozaiki. Semiotyzacja pożaru, sposoby przekodowywania wyjściowych komunikatów medialnych wskazują również, co ciekawe, na witalność i nośność podstawowych kulturowych słowników, kluczowych, źródłowych zasobów semiotycznych - przy czym fakt ich używania przez wspomniane rozmaite „bańki”, a także odmienne sposoby ich wykorzystywania pokazują, z jednej strony, bogactwo semantyczne tych kodów, z drugiej - właśnie walkę, która toczy się o możliwości, granice i zasady ich użytkowania (najprościej rzecz ujmując - byłby to konflikt między „kanonem” a „archiwum”34).

${ }^{34}$ Aleida Assmann przeprowadza podział na aktywne i bierne formy pamięci, z którymi z kolei łączy odpowiednio pojęcia „kanonu” i „archiwum”. Ten pierwszy, przynależąc do sfery pamiętania aktywnego, jest swego rodzaju „kanonem klasyki”, zbiorem Bildungstexte, stanowiąc rezerwuar pamięci, jest bowiem przyswajany i interpretowany przez kolejne pokolenia, co pozwala im wejść w obszar wspólnego doświadczenia kulturowego z poprzednimi generacjami. Archiwum z kolei przynależy do modelu pasywnego, mieszcząc się „w połowie drogi między kanonem a zapomnieniem"; to rezerwuar tekstów i artefaktów, które w stanie pewnego zawieszenia oczekują na ponowne użycie. Społeczny stosunek do zasobów kanonicznych i archiwalnych jest odmienny - te drugie mogą być używane bardziej „swobodnie”. Zob. A. Assmann, Walka o kanon-polityka tożsamościowa w medium literatury, [w:] eadem, Wprowadzenie do kulturoznawstwa Podstawowe 
Co ciekawe, ogień jest bardziej nośny semiotycznie, jest symbolem mocniejszym niż katedra - w większości odczytań konotującym jednak głównie zniszczenie, karę, śmierć, upadek, koniec, zagładę, przestrogę (nie zaś oczyszczenie, łaskę, Boską obecność, ciepło, życie etc.). Pożar skanalizował zatem rozmaite nastroje apokaliptyczne, choć źródło i kształt upadku widziane są różnie, w zależności od przyjętej perspektywy światopoglądowej: „upadek Europy”, „upadek wartości”, „dominacja islamu”, „utrata tożsamości”, „kara za moralny upadek Kościoła” versus „społeczna ślepota”, „religijne zniewolenie”, „katastrofa ekologiczna”, „kryzys klimatyczny”, "globalne ocieplenie”, „globalna krótkowzroczność”, „chciwość”, „kapitalizm”, „zysk”. Ogień trawiący katedrę (a także, w kontekście niektórych z omówionych powyżej komunikatów - lasy) jest zatem ogniem pochłaniającym, choć jednocześnie wciąż jeszcze nie musi być ogniem piekielnym, lecz ostrzeżeniem, nawołaniem do (rozmaicie definiowanego) opamiętania. Nastroje quasi-apokaliptyczne równoważone są tradycyjnie przez elementy karnawalizacji, czyli, w tym przypadku, przez memy, które ironicznie przekodowują dramatyczne komunikaty, a nawet - samo zjawisko semiotyzacji pożaru.

We wszystkich tych tekstach ujawniają się pewne podstawowe mechanizmy kultury: skomplikowane relacje i granice między rozmaitymi światoobrazami, napięcie między statyką i dynamiką kultury, zdolność kultury do autokomunikacji i autorefleksji, kulturowa (a szerzej - ludzka) skłonność do semiotyzacji zjawisk, mechanizmy twórczego przekładu, rola intertekstualności w produkcji kulturowej, w końcu wspomniana już nośność treści kanonicznych, stojących w centrum kulturowego uniwersum znaczeń. Ujawnia się tu w końcu problem polityczności w sensie źródłowym - pytania o tożsamość, o jej elastyczność, o sposoby jej ewentualnej konserwacji, o możliwe podstawy wspólnoty, w końcu - o polityczność religii, ekologii i globalnej ekonomii.

terminy, problemy, pytania, tłum. i wstęp A. Artwińska, K. Różańska, Poznań 2015, s. 321-322; eadem, Kanon i archiwum, [w:] eadem, Między historia a pamięcią, op. cit., s. $74-88$. 


\section{Bibliografia}

Aleida Assmann, Między historia a pamięcią. Antologia, red. i posłowie M. Saryusz-Wolska, Wydawnictwa Uniwersytetu Warszawskiego, Warszawa 2013.

Aleida Assmann, Walka o kanon - polityka tożsamościowa w medium literatury, [w:] eadem, Wprowadzenie do kulturoznawstwa. Podstawowe terminy, problemy, pytania, tłum. i wstęp A. Artwińska, K. Różańska, Wydawnictwo Nauka i Innowacje, Poznań 2015.

Wojciech Józef Burszta, Kotwice pewności. Wojny kulturowe z popnacjonalizmem $w$ tle, Iskry, Warszawa [cop. 2013].

Umberto Eco, Sześć przechadzek po lesie fikcji, tłum. J. Jarniewicz, Społeczny Instytut Wydawniczy Znak, Kraków 1996.

Umberto Eco, Płomień jest piękny, [w:] idem, Wymyślanie wrogów i inne teksty okolicznościowe, tłum. A. Gołębiowska, T. Kwiecień, Dom Wydawniczy Rebis, Poznań 2011.

Loulla-Mae Eleftheriou-Smith, Monkey Appears to Mourn 'Dead' Infant in Moving Photograph, “The Independent”, 10.05.2017; https://www.independent.co.uk/ news/world/asia/monkey-mourning-dead-baby-photo-infant-emotional-india-a7728226.html [dostęp: 6.09.2019].

Dorothea Forstner, Świat symboliki chrześcijańskiej, tłum. i oprac. W. Zakrzewska,

P. Pachciarek, R. Turzyński, Instytut Wydawniczy PAX, Warszawa 1990.

Paweł Gocko, Mistyczne znaczenie ognia, „Elpis. Czasopismo Teologiczne Katedry Teologii Prawosławnej Uniwersytetu w Białymstoku” 2017, nr 19.

Magdalena Kamińska, Memosfera. Wprowadzenie do cyberkulturoznawstwa, Galeria Miejska Arsenał, Poznań 2017.

Leksykon liturgii, oprac. B. Nadolski, Pallotinum, Poznań 2006.

Jurij Łotman, Uniwersum umysłu. Semiotyczna teoria kultury, tłum. i przedmowa

B. Żyłko, Wydawnictwo Uniwersytetu Gdańskiego, Gdańsk 2008.

Marcin Napiórkowski, Powstanie umarłych. Historia pamięci 1944-2014, Wydawnictwo „Krytyki Politycznej”, Warszawa 2016.

Jan Kanty Pytel, Symbolika ognia w Piśmie Świętym, „Ruch Biblijny i Liturgiczny”1989, t. 42 , nr 2.

Andrzej Rojewski, Symbolika światła w liturgii, „Studia Płockie” 2010, nr 38.

Weronika Rokicka, Europa płacze nad katedra Notre Dame, co wiemy o innych wydarzeniach na świecie?, „Krytyka Polityczna”, 20 kwietnia 2019; 
https://krytykapolityczna.pl/swiat/europa-placze-nad-katedra-notre -dame-co-wiemy-o-innych-wydarzeniach-na-swiecie/. Antoni Tronina, Eucharystia. Ogień i duch, „Verbum Vitae” 2005, nr 8.

\section{Źródła internetowe}

http://krysztofiak-wojciech.blogspot.com/2019/04/pozar-w-notre-dame-jako-hierofania-czy.html.

http://wyborcza.pl/7,75398,23827676,dzieciece-buciki-na-murach-kosciolow -polska-upamietnia-ofiary.html.

https://aszdziennik.pl/127335, desperacja-lasu-w-amazonii-zbudowal-sobie-katedre-z-notre-dame-zeby-ktos?fbclid=IwAR1DZ7lKKXkUm8wlJWYZjjdrcxEX71398oKoOBqk5s5Kxu4gwYiPHtv1H3g.

https://biblia.deon.pl/rozdzial.php?id=351\&werset=32\#W32.

https://www.facebook.com/gretkowska.manuela/posts/2222652697827274.

https://www.facebook.com/iwona.kopacz2/posts/2314503568596931.

https://www.facebook.com/osrodek.monitorowania/posts/953909964784137.

https://www.facebook.com/permalink.php?story_fbid=2027198004248665 \&id=1979581615676971.

https://www.rp.pl/Kosciol/180829499-Buciki-na-kosciolach-Akcja-upamietniaofiar-pedofilii.html.

https://www.tvn24.pl/wiadomosci-z-kraju,3/buciki-przed-kosciolami-druga-odslona-akcji-baby-shoes-remember,963927.html.

\section{Źródła ilustracji}

Il. 1-4. Zrzuty ekranu $z$ archiwum autorki.

Il. 5. http://krysztofiak-wojciech.blogspot.com/2019/04/pozar-w-notre-dame-ja ko-hierofania-czy.html.

Il. 6. http://www.europereloaded.com/jerusalems-al-aqsa-mosque-catches-fire-thesame-time-as-notre-dame/.

Il. 7. https://demotywatory.pl/4921698/Muzulmanie-smiali-sie-z-pozaru-KatedryNotre-Dame.

Il. 8. https://www.facebook.com/osrodek.monitorowania/posts/953909964784137.

Il. 9. http://picpanzee.com/zane_tt_a.

Il. 10. https://twitter.com/totylkoteoria/status/1165027420799479808.

Il. 11. L.-M. Eleftheriou-Smith, Monkey Appears to Mourn 'Dead' Infant in Moving Photograph, „The Independent”, 10.05.2017; https://www.independent.co.uk/ 
news/world/asia/monkey-mourning-dead-baby-photo-infant-emotional-in dia-a7728226.html.

Il. 12. https://aszdziennik.pl/127335,desperacja-lasu-w-amazonii-zbudowal-sobiekatedre-z-notre-dame-zeby-ktos?fbclid=IwAR1DZ7lKKXkUm8wlJWYZjj drcxEX71398oKoOBqk5s5Kxu4gwYiPHtv1H3g.

Il. 13. https://www.wykop.pl/cdn/c3201142/comment_D9WQiBWK onnco8nib6a gOErEIMIIY22N,w400.jpg.

Il. 14. https://besty.pl/3992380.

Il. 15. https://img.joemonster.org/images/vad/img_47686/378f9281dcf8e68508 f5a59af6804024.jpg.

Il. 16. https://pobierak.jeja.pl/images/0/5/c/494575_wspolpraca.jpg.

Il. 17. https://i1.kwejk.pl/k/obrazki/2019/04/6XS99ByHTF6AkLm8.jpg.

Il. 18. https://i1.kwejk.pl/k/obrazki/2019/04/7O9zY62zkJKzTR0c.jpg.

Il. 19. https://img.besty.pl/images/399/25/3992599.jpg.

Il. 20. https://www.wykop.pl/cdn/c3201142/comment_YT3nIpzBnLn CV6LEHfG gJ7DQX4VBchZ2.jpg.

Il. 21. https://img.besty.pl/images/399/22/3992289.jpg.

Il. 22. http://memytutaj.pl/uploads/2019/04/16/5cb64706bfdc5.jpg.

Il. 23. https://kwejk.pl/obrazek/3372623/beka-z-pozaru.html.

Il. 24. https://i1.kwejk.pl/k/obrazki/2019/04/YNvzXs1FMJZhsBHj.jpg.

\section{Internets Are Burning. On Some Semiotizations of the Notre Dame Fire}

The aim of the article is to analyse some online reactions to the Notre Dame fire, especially the content of social media. The fire has often been interpreted through biblical symbolism as a sign of God's presence, a warning or even a punishment. At the same time, various information bubbles have used the opportunity to discuss some basic global issues, e.g. climate change, comparing the burning cathedral to the burning Siberian and Amazonian forests. There are also some examples of the pure netlore which can be seen as an element of the process of carnivalization - a way out from the apocalyptic narratives of any kind.

Keywords: Notre Dame Cathedral, fire, symbolism of fire, culture wars, information bubble 